Primljeno: 23.2.2021.

Prihvaćeno: 14.7.2021.

DOI: 10.36506/av.64.8

\author{
Ana Tuk \\ Državni arhiv u Varaždinu \\ Varaždin, Hrvatska \\ ana@dav.hr
}

\title{
GRADSKO POGLAVARSTVO VARAŽDIN \\ U MEĐURATNOM RAZDOBLJU (1918.-1941.)
}

\author{
UDK: 352(497.523)“19“(093) \\ 94(497.523)“1918/1945 \\ $930.25(497.523) “ 1918 / 1941 “(093)$
}

Prethodno priopćenje

Članak razmatra ustroj, djelokrug $i$ teritorijalnu nadležnost Gradskoga poglavarstva Varaždin izmecu dva svjetska rata. Prikazana su tri mecusobno koordinirana tijela Gradskoga poglavarstva: gradsko zastupstvo kao lokalno predstavničko tijelo, odbori kao savjetodavna tijela zastupstva i gradsko poglavarstvo kao izvršno tijelo. U poglavlju o zastupstvu kronološki su predstavljeni svi mandati zastupstva, načelnici $i$ vladini povjerenici koji su upravljali gradom. U narednom poglavlju razraden je djelokrug svakoga odbora zasebno i taksativno su pobrojani svi odbori izabrani u promatranom razdoblju. Posljednje poglavlje analizira organizaciju ustrojbenih jedinica u kojima se je odvijalo poslovno djelovanje poglavarstva. Pogled na djelovanje gradske uprave zaokružen je zakonskom regulativom i naznakom unitarističko-centralističkih $i$ apsolutističkih tendencija koje su oblikovale svekoliku društveno-političku zbilju, uključujući $i$ rad jedinica lokalne vlasti.

Ključne riječi: gradsko zastupstvo (vijeće); gradsko poglavarstvo; načelnik, odbori; vladin povjerenik; gradska uprava; gradska samouprava; upravna povijest 


\section{Uvod}

Međuratnu povijest Varaždina problematiziraju desetci stručno-znanstvenih tekstova, uglavnom obrađeni s društvenih, gospodarskih, političkih i kulturoloških aspekata. ${ }^{1}$ Za razliku od toga, upravna povijest samo je okrznuta u pojedinim publikacijama, ${ }^{2}$ ali sustavnomu pregledu do sada nije posvećena veća pažnja. Ovaj članak otvara i analizira pitanje uprave Gradskoga poglavarstva Varaždin (GPV) te će poslužiti kao ishodište daljnjih sustavnijih istraživanja upravne povijesti. Uvod u strukturu GPV-a donosi poglavlje o zakonskoj regulativi, uključujući zakone i uredbe koje su definirale povijest i razvojni tijek gradske (samo)uprave. Gradsko je poglavarstvo prikazano kao upravna organizacija koja obavlja društvene poslove preko svojih organizacijskih jedinica, odnosno tijela, od kojih svako ima specifičnu svrhu i međusobno koordinirane obveze. ${ }^{3}$ Članak analizira ustroj i djelokrug gradskoga zastupstva kao lokalnoga predstavničkoga tijela, odbora kao savjetodavnih tijela zastupstva i poglavarstva kao izvršnoga tijela koje obavlja samoupravne i upravne zadatke koji su mu stavljeni u nadležnost. Dužnost načelnika, kao četvrte karike u organizacijskom sustavu GPV-a, obrađena je unutar poglavlja o zastupstvu i poglavarstvu, u čijim je okvirima načelnik imao predstavničko-izvršnu ulogu. Poglavlje o gradskom zastupstvu, za razliku od ostalih obrađenih isključivo kroz prizmu upravne povijesti, pruža suženi pogled i u političku zbilju vremena. Naime, pored ustroja i nadležnosti zastupstva, poglavlje donosi kronološki pregled mandata, čije je trajanje i djelovanje ovisilo o stranačkim razmimoilaženjima i ideološko-političkim (ne)suglasjima. U dvadesetim je godinama lokalna politička zbilja utjecala na (ne)stabilnost mandata, a od 1929. režimska je ideologija imala ključnu i apsolutnu ulogu u opstojnosti jednoga saziva. Tako se je i politička povijest na mala vrata uvukla u okvire ovoga rada.

Prije prelaska na samu temu, potrebno je razjasniti moguće terminološke dvojbe. Izraz grad u članku ne označava određeno urbano naselje, nego se koristi isključivo u kontekstu gradske općine kao upravno-teritorijalne jedinice. U pravnoj regulativi promatranoga razdoblja nazivi grad i gradska općina rabe se kao sinonimi, a naziv općina uglavnom se odnosi na seoske općine, iako može biti shvaćen i u širem značenju koje u sebi objedinjuje i seoske i gradske općine. U ovom se članku nazivi grad i gradska opcína koriste kao istoznačni. Tijekom vremena, točnije 1934., nazivi zastupstvo i načelnik zamijenjeni su nazivima vijeće i predsjednik. U poglavlju posvećenom gradskomu zastupstvu koristi se za razdob-

\footnotetext{
1 Usp. Vladimir Huzjan i Ivan Obadić, "Historiografija varaždinskog kraja u 20. stoljeću," Historia Varasdiensis 1 (2012): str. 67-73.

2 Usp. Spomenka Težak, "Varaždinska gradska vlast u 20. stoljeću," u 800 godina slobodnog kraljevskog grada Varaždina 1209.-2009., ur. Miroslav Šicel i Slobodan Kaštela (Varaždin: Zavod za znanstveni rad Varaždin HAZU, 2009), str. 159-168.
}

3 Eugen Pusić, Nauka o upravi (Zagreb: Pravni fakultet, 1986), str. 4-7. 
lje 1918.-1934. naziv zastupstvo, a za razdoblje 1934.-1941. naziv vijeće. U ostalim dijelovima članka korišten je u općem značenju naziv zastupstvo. Po istom načelu korišten je i naziv načelnik, odnosno predsjednik.

Pri izradi članka prvenstveno je istraženo gradivo fonda HR-DAVŽ-649. Gradsko poglavarstvo Varaždin, uz konzultiranje i drugih fondova, uglavnom tijela nadležnih GPV-u, kao što su Zemaljska vlada za Hrvatsku i Slavoniju, Pokrajinska uprava za Hrvatsku i Slavoniju, Zagrebačka oblast, Savska Banovina i Banovina Hrvatska. Uvid u zakonsku regulativu pružila su službena glasila, srodna literatura i dio spomenutoga arhivskoga gradiva.

\section{Gradska (samo) uprava u okviru zakonodavne regulative}

Uspostavom Kraljevstva Srba, Hrvata i Slovenaca (1918.-1921.), kasnije Kraljevine Srba, Hrvata i Slovenaca (SHS) (1921.-1929.), novi se je poredak u kratkom vremenu manifestirao na društveno-političkom planu, a upravno je poslovanje, osobito lokalnih samouprava, samo nastavilo kontinuirani tijek započet u Austro-Ugarskoj Monarhiji. Vlast Kraljevstva SHS odlučila je 1918. zadržati postojeće upravne sustave i partikularno zakonodavstvo iz prethodnoga razdoblja, te postepeno uvoditi nove zakone i reforme kako se u državnoj upravi ne bi osjetio administrativni skok. ${ }^{4}$ Regent Aleksandar I. Karađorđević izjavio je 1. prosinca da za svaku pokrajinu vrijede oni zakoni koji su bili na snazi za vrijeme prevrata, ${ }^{5}$ a ban Antun pl. Mihalović uputio je brzojav svim tijelima vlasti neka u kontinuitetu nastave svoje uredovanje. ${ }^{6}$ Tako je i Gradsko poglavarstvo Varaždin nastavilo djelovati u istom sastavu i prema osnovnom zakonu o gradskim općinama tzv. Zakonu ob ustroju gradskih obćinah u kraljevinah Hrvatskoj i Slavoniji od 21. lipnja 1895.' (dalje: ZGO iz 1895.) i statutu slobodnoga i kraljevskoga grada Varaždina iz 1895./1896. godine. ${ }^{8}$

Sukladno navedenomu zakonu Varaždin je ulazio u prvu skupinu gradova, zajedno sa Zagrebom, Osijekom i Zemunom, koji su bili neposredno podređeni Kraljevskoj hrvatsko-slavonsko-dalmatinskoj zemaljskoj vladi. ${ }^{9}$

\footnotetext{
4 Stipica Grgić, Između režimske ideologije i potreba građana: Savska banovina 1929-1939 (Zagreb: Fakultet hrvatskih studija Sveučilišta, 2020), str. 54.

5 Dr. Bogdan Stopar nije veliki župan grada Varaždina, Slobodni gradanin 2, br. 8 (31. siječnja 1920): str. 2.

6 HR-DAVŽ-649. GPV, 3.1.3. Redovni spisi, br. 11208/1918.

7 Zakon ob ustroju gradskih obćinah u kraljevinah Hrvatskoj i Slavoniji, Sbornik zakonah i naredabah valjanih za Kraljevine Hrvatsku i Slavoniju 34/1895.

8 Statut grada Varaždina donesen je na redovnoj skupštini 15. studenoga 1895., a njegove izmjene 16. svibnja 1896. godine.

9 Od gradova drugoga reda Karlovac je s premašenih 10.000 stanovnika postao 1918. grad prvoga reda podređen neposredno Zemaljskoj vladi. Usp. Zakon od 29. ožujka 1918. kojim se preinačuju neke
} 
Poslove gradske općine obavljalo je gradsko zastupstvo, gradski načelnik i gradsko poglavarstvo. Na čelu grada Varaždina stajao je gradski veliki župan, kojega je imenovao kralj. On je nadzirao poslove gradske samouprave i javne uprave prenijete u djelokrug poglavarstva.

Gradska je općina obavljala sve upravne poslove koje je propisala i na nju prenijela državna vlast i unutarnje poslove koji su se odnosili na njezino područje i životne uvjete njezinih stanovnika. Predstavljala je samoupravnu jedinicu $s$ ograničenom autonomijom, pri čemu se je samouprava manifestirala u mogućnosti stanovnika da biraju svoje predstavnike u zastupstvo te u pravu zastupstva da donosi zaključke o svim gradskim pitanjima i raspolaže vlastitim financijama. Ograničenje samouprave sastojalo se je u pravu nadležnoga tijela da odobri odnosno poništi gradske akte $\mathrm{i}$ "iz važnih razloga« raspusti zastupstvo i postavi svojega povjerenika.

Ulaskom u novu državu gradovi su pretpostavili da je na pomolu donošenje zakona koji će učvrstiti i proširi gradsku autonomiju. S obzirom na to da je nova država objedinila nekoliko područja s različitim pravnim tradicijama, kao jedan od glavnih zadataka vlade nametnulo se je pitanje izjednačenja zakona. ${ }^{10}$ No, kako novi zakon o gradskim općinama nije bio presudan za funkcioniranje države, njegovo je donošenje protegnuto čak do 1934. godine.

Dana 1. studenoga 1919. donesena je Uredba o izboru gradskih zastupstva za gradove Hrvatske i Slavonije, kojom je redefinirano izborno pravo ZGO-a iz 1895. godine. ${ }^{11}$ Uredbom je pravo glasa prošireno za muškarce (prag starosti smanjen je s 24 na 21 godinu i ukinut je izborni cenzus) te je dano pravo glasa ženama koje samostalno vode gospodarstvo, obrtnu odnosno trgovačku radnju ili koje su sa završena četiri razreda škole namještene u javnoj ili privatnoj službi. Sama Uredba nije zadirala u ustroj i nadležnost gradskih općina, ali je svojom prvom stavkom da se "gradska zastupstva imaju na novo izabrati s obzirom na preinake izbornog reda« utjecala na raspuštanje dotadašnjih zastupstava. Uredba je s manjim izmjenama i dopunama 1 . veljače 1922. pretočena u zakon. ${ }^{12}$ Člankom 7. propisano je da su Varaždin i ostali gradovi prvoga stupnja obvezni dostavljati izborne liste Odjeljenju za unutarnje poslove Pokrajinske uprave za Hrvatsku i Slavoniju. Naime, Pokrajinska je uprava, umjesto ukinute Zemaljske vlade, bila u razdoblju 1921.-1924. direktno nadležno tijelo GPV-u.

\footnotetext{
ustanove zakona od 21. lipnja 1895. o ustroju gradskih općina u Kraljevinama Hrvatskoj i Slavoniji, Zbornik zakona i naredaba valjanih za Hrvatsku i Slavoniju 6/1918.

10 Marko Pavlović, "Problem izjednačenja zakona u Kraljevini Srba, Hrvata i Slovenaca / Jugoslaviji," Zbornik Pravnog fakulteta u Zagrebu 68, br. 3-4 (2018): str. 493-523.

11 Uredba o izboru gradskih zastupstva za gradove Hrvatske i Slavonije, Zbornik zakona i naredaba valjanih za Hrvatsku i Slavoniju 68/1919.

12 Zakon o izboru gradskih zastupstva za gradove Hrvatske i Slavonije, Službene novine Kraljevine Srba, Hrvata i Slovenaca 107/1922.
} 
Uredbom o podeli zemlje na oblasti od 26. travnja $1922 .{ }^{13}$ provedena je tijekom 1924. upravna podjela na oblasti. Pokrajinska uprava za Hrvatsku i Slavoniju postupno je ukidana od kraja 1924. do 1. ožujka 1925. godine, a sukladno Uredbi područje bivše Varaždinske županije ušlo je u sastav novoosnovane Zagrebačke oblasti. Ukinuće Varaždinske županije, kao jedne od najstarijih županija na području Hrvatske, izazvalo je val nezadovoljstva među gradskim zastupnicima. Raspuštanjem županije Varaždin je izgubio ulogu upravno-političkoga središta i velik broj ustanova izvršnoga statusa. ${ }^{14}$ Novom podjelom, veliki župan Zagrebačke oblasti postaje novi nadzorni organ GPV-u te u razdoblju 1924.-1929. potvrđuje odnosno ukida zaključke zastupstva, izuzev u financijskim pitanjima (donošenje proračuna, prekoračenje budžeta, uzimanje zajmova, isplata obveznica, naplata poreza i dr.), za koje je bilo nadležno Ministarstvo financija. Ministarstvo unutrašnjih poslova rješavalo je žalbe protiv odluka oblasnoga velikoga župana o izboru gradskoga zastupstva i imalo je pravo nadzora nad pojedinim samoupravnim poslovima gradskih općina. ${ }^{15}$

Istoga dana, 6. siječnja 1929., kada je kralj manifestom ukinuo Ustav, raspustio parlament, zabranio rad stranaka i proglasio apsolutističku monarhiju, donio je i Zakon o izmeni Zakona o opštinama i oblasnim samoupravama, kojim su raspuštene oblasne, općinske i gradske (samo)uprave. ${ }^{16} \mathrm{U}$ svim općinama nove je uprave trebao postaviti nadležni oblasni veliki župan. Iako je Zakonom propisano da se uprave u cijeloj državi raspuštaju dana 6. siječnja, ipak su općinske uprave nastavile djelovati naredna dva-tri mjeseca do konačnih rješenja velikih župana. U ožujku je središnja državna uprava naredila podređenim tijelima da započnu sa smjenama općinskih uprava na području Hrvatske. ${ }^{17}$ I u Varaždinu je u ožujku imenovano novo zastupstvo, ali tek nakon ostavke gradonačelnika i rješenja velikoga župana o prihvaćanju ostavke. ${ }^{18}$ Dana 14. siječnja 1929. Zakonom o ukidanju Zakona o izboru organa oblasne, sreske i opštinske uprave, ${ }^{19} \mathrm{u}$ svega dva članka, ukinuta je mogućnost slobodnih izbora i svi izborni postupci propisani dotadašnjim zakonima, a zakonski je afirmirano imenovanje povjere-

\footnotetext{
13 Uredba o podeli zemlje na oblasti, Službene novine Kraljevine Srba, Hrvata i Slovenaca 92/1922.

14 Usp. Mira Kolar-Dimitrijević, "Reakcije Varaždinaca na ukinuće Varaždinske županije 1922. godine i posljedice tih promjena," u 800 godina slobodnog i kraljevskog grada Varaždina 1209.-2009., ur. Miroslav Šicel i Slobodan Kaštela (Varaždin: Zavod za znanstveni rad Varaždin HAZU, 2009), str. 285-298.

15 HR-HDA-141. ZO, spisi Velikog župana, sv. III-12, br. 30532/1925.

16 Zakon o izmeni Zakona o opštinama i oblasnim samoupravama, Zbornik zakona, uredbi i naredbi 7/1929.

17 Stipica Grgić, "Općinske uprave u vrijeme šestosiječanjske diktature," Časopis za suvremenu povijest 45, br. 1 (2013): str. 89-117.

18 HR-DAVŽ-649. GPV, 2.4. Povjerljivi spisi, Rješenje Velikog Župana Zagrebačke oblasti br. 3304 Pov. od 8. ožujka 1929., br. 20/1929.

19 Zakon o ukidanju Zakona o izboru organa oblasne, sreske i opštinske uprave, Zbornik zakona, uredbi i naredbi 17/1929.
} 
nika i gradskih zastupstva. Ukidanje dotadašnje zakonske regulative, strogi hijerarhijski nadzor, imenovanje gradskih vijeća i vladinih povjerenika bliskih državnomu režimu te potpuno negiranje izbornih načela, kao zaloga kakve-takve autonomije, dovelo je do sužavanja samoupravnih prava gradskih općina. Iako su oblasti kao upravno-teritorijalne jedinice formirane 1924., zakonom od 3. listopada $1929 .{ }^{20}$ promijenjeno je ime države u Kraljevina Jugoslavija te je provedena nova administrativno-prostorna reorganizacija: na mjesto oblasti formirano je devet banovina. Izuzev manjih odstupanja, većina prostora današnje Hrvatske podijeljena je na Savsku banovina sa sjedištem u Zagrebu i Primorsku sa sjedištem u Splitu. ${ }^{21}$ Zakonitost zaključaka gradskoga zastupstva od 1929. nadalje provjeravala je Banska uprava, a ban je provodio nadzor nad poslovima varaždinske gradske uprave i imenovao gradske načelnike i zastupnike, ali tek nakon podrobne redarstvene provjere i potvrde ministra unutrašnjih poslova.

Tridesetih godina ponovno je otvoreno pitanje novoga zakona o gradovima i Ministarski je savjet 11. prosinca 1930. pristupio izradi zakona. Savez gradova $^{22}$ iznio je svoja očekivanja: gradska organizacija treba omogućiti ostvarenje prave samouprave te svaki grad treba samostalno, preko svojih slobodno izabranih tijela i svojim sredstvima, upravljati onim što se tiče njega i njegova stanovništva. ${ }^{23}$ Zakon je nakon dugogodišnjega iščekivanja ugledao svjetlo dana 22. srpnja, a na snagu je stupio 23. rujna 1934. godine. Sukladno Zakonu o gradskim opštinama ${ }^{24}$ (ZGO) Varaždin je zadržao status grada. Tijela gradske općine od tada su činili gradsko vijeće i predsjednik općine. Propisano je (ali ne i realizirano) da se dvije trećine vijećnika i predsjednik biraju javnim glasovanjem, a jednu trećinu da postavlja ban.

Djelokrug grada obuhvaćao je i nadalje sve poslove koji se tiču neposrednoga interesa grada i pridonose njegovu ekonomskomu, kulturnomu i socijalnomu napretku te sve poslove državne uprave regulirane postojećim zakonskim propisima. U samoupravni djelokrug pripadalo je upravljanje gradskom imovinom, unaprjeđenje građevinsko-komunalne infrastrukture i narodnoga gospodarstva, briga o socijalno-zdravstvenim uvjetima i razvoju prosvjete. Kao prvostupanjska vlast gradovi su obavljali poslove opće uprave iz zdravstvenoga i veterinarskoga, tržišnoga, građevinsko-komunalnoga, požarnoga i poljoprivrednoga područja. Ministar unutrašnjih poslova mogao je smijeniti predsjednika i cijelo vijeće ako nisu zadovoljavali zakonske uvjete ili u slučaju neizvršavanja obveza. Predsjednik gradske općine dostavljao je sve normativne akte na provjeru nadzor-

\footnotetext{
20 Zakon o nazivu i podjeli Kraljevine na upravna područja, Zbornik zakona, uredbi i naredbi 84/1929.

21 Grgić, Izmedu režimske ideologije i potreba gradana, str. 153-154.

22 Osnovan je u svibnju 1927. u Zagrebu s ciljem razvijanja samouprave gradova i međusobne suradnje.

23 HR-DAVŽ-649. GPV, 15.1. Savez gradova Kraljevine SHS/Jugoslavije, nacrt predstavke Saveza gradova Kraljevine Jugoslavije u predmetu donošenja novog zakona o gradovima, br. 2976/1931.

24 Zakon o gradskim opštinama, Zbirka zakona i uredaba 177/1934.
} 
noj vlasti (banu, ministru unutrašnjih poslova ili, u slučaju financijskih predmeta, ministru financija), koja ih je u roku od mjesec dana trebala usvojiti ili poništiti, a zapisnike sjednica vijeća banskoj vlasti, koja je u roku od osam dana donosila rješenje o provođenju ili obustavi odluke vijeća. Novi ZGO uveo je mogućnost ulaganja žalbe protiv odluka nadzorne vlasti Državnomu savjetu, najvišemu upravnomu sudu Kraljevine Jugoslavije.

Iako je ZGO-om iz 1934. detaljno propisan izborni postupak i definirano je da odluku o raspisivanju izbora donosi ministar unutrašnjih poslova (ali ne i rok u kojem to mora učiniti), njegova primjena nikada nije zaživjela jer izbori za gradska vijeća nisu raspisani u razdoblju 1934.-1941. Naime, imenovanje načelnika i gradskih vijećnika ili postavljanje vladinih povjerenika započeto dvadesetih godina, ozakonjeno diktaturom 1929., nastavljeno je tijekom narednoga razdoblja i, pozivanjem na čl. 147. ZGO-a iz 1934., prema kojemu se do raspisivanja izbora gradska tijela određuju po dotadašnjim propisima, postalo je trajnom praksom tridesetih. ${ }^{25}$ Često su i službenici gradske uprave, birani putem natječaja od strane vijeća, a potom potvrđivani odlukom nadzorne vlasti, postali "strogo kontrolirani kotačić u mehanizmu nove režimske državne vlasti«. ${ }^{26}$ Takvom je praksom gradska samouprava uvelike okrnjena i svedena na mogućnost rješavanja pojedinih pitanja mjesnoga interesa (a u slučaju postavljenoga povjerenika isključivo na obavljanje tekućih poslova), ali ne i na pravo vijećnika da donose gospodarske i financijske odluke, iznose političke stavove i usmjeravaju lokalnu političku klimu, kao i na pravo građana da samostalno izabiru svoje predstavnike. Po donošenju ZGO-a 1934. Gradsko poglavarstvo trebalo je uskladiti svoje poslovanje $s$ odredbama novoga zakona. Ministarstvu unutrašnjih poslova upućena je molba da se pored poslova opće uprave prvostupanjskih vlasti u nadležnosti grada Varaždina ostave i poslovi prvoga stupnja iz Zakona o radnjama. ${ }^{27}$ Člankom 81. propisana mogućnost da se pojedini stalni poslovi iz domene predsjednika prebace na potpredsjednika u GPV-u nije aktivirana, te je potpredsjednik nastavio i nadalje mijenjati predsjednika u slučaju spriječenosti, ali bez stalne nadležnosti. Člankom 148. propisano je da su nova gradska vijeća dužna u roku od godinu dana donijeti nove statute i uredbe o organizaciji. Banska uprava pojasnila je da donošenje statuta sukladno ZGO-u iz 1934. isključivo pripada u nadležnost gradskoga vijeća izabranoga sukladno novomu zakonu. ${ }^{28} \mathrm{~S}$ obzirom na to da vijeće nije izabrano, niti novi statut nije donesen.

\footnotetext{
25 Suzana Leček, "Izbor ili imenovanje - problem gradske (samo)uprave u Slavonskom Brodu 1918.1941.," Casopis za suvremenu povijest 45, br. 1 (2013): str. 9-33.

26 Danijel Vojak, "Političko-upravne prilike na području samoborskog kotara za vrijeme šestosiječanjske diktature (1929.-1935.)," Ćasopis za suvremenu povijest 45, br. 1 (2013): str. 119-154.

27 HR-DAVŽ-649. GPV, 1.1. Zapisnici sjednica Gradskog zastupstva, zapisnik od 30. studenoga 1934., str. 65., točka 27.

28 HR-DAVŽ-649. GPV, 3.1.3. Redovni spisi, uputstvo br. 36286-II-3-1935. Banske uprave, upravno odjeljenje, br. 14308/1927.
} 
S obzirom na to da su mnoge stavke novoga zakona ograničavale gradsku autonomiju, Savez gradova podnio je 1935. i 1937. godine prijedloge za reviziju zakona Kraljevskoj vladi, ali promjeni zakonske regulative vlast nije pristupila i ZGO iz 1934. ostao je na snazi do kraja istraživanoga razdoblja. ${ }^{29}$

Uspostavom Banovine Hrvatske nije došlo do promjena u zakonskoj regulativi jer je planove o donošenju novoga zakona zasjenila nepovoljna vanjskopolitička situacija. S obzirom na to da je jedini aktualni zakon bio onaj iz 1934., i banska je vlada pozivanjem na čl. 147 tijekom travnja i svibnja 1940. imenovala predsjednike i nova gradska vijeća u svim gradovima. ${ }^{30}$

\section{Teritorijalna nadležnost}

Sukladno Zakonu o ustroju županija od 5. veljače 1886. grad Varaždin nalazio se je 1918. na području Varaždinske županije i bio je njezino upravno sjedište. ${ }^{31}$ Teritorijalna nadležnost gradske općine obuhvaćala je područje samoga grada i dva obližnja sela: Varaždin Breg i Novo Selo (od 1948. Novo Selo na Dravi). ${ }^{32}$ Naredbom bana od 4. prosinca 1920. br. 47221 odcijepljeno je $s$ danom 1. siječnja 1921. godine selo Šandorovec od upravne općine Biškupec i pripojeno gradskoj općini Varaždin. ${ }^{33}$ Usprkos zahtjevima drugih naselja (Gornjega i Donjega Kneginca, Lužana, Biškupca, Kuršanca) za priključenjem gradu, teritorijalna nadležnost gradske općine Varaždin ostala je identična od 1921. do 1941. i obuhvaćala je područje grada i tri navedena sela.

\section{Analiza ustroja i djelokruga Gradskoga poglavarstva Varaždin}

\subsection{Gradsko zastupstvo (vijeće)}

Sukladno ZGO-u iz 1895. gradsko zastupstvo Varaždina imalo je 30 zastupnika. Gradski zastupnici birani su na šest godina, $s$ time da je treće godine mandata polovica zastupnika izabranih ždrijebom odstupala $s$ dužnosti, a 15 novoizabranih popunjavalo zastupstvo. Ako bi zastupničko mjesto bilo ispražnjeno, popunjavano je novim zastupnikom $s$ iste izborne liste $s$ koje je bio $\mathrm{i}$ njegov prethodnik. Sukladno Uredbi o izboru gradskih zastupstva iz 1919. za

\footnotetext{
29 HR-DAVŽ-649. GPV, 15.1. Savez gradova Kraljevine SHS/Jugoslavije (kut. 180).

30 Leček, "Izbor ili imenovanje," str. 30.

31 Zakon ob ustroju županijah i uredjenju uprave u županijah i kotarih, Sbornik zakonah i naredabah valjanih za Kraljevine Hrvatsku i Slavoniju 8/1886.

32 Naredba o službenim imenima upravnih i poreznih općina te prebivališta u kraljevinama Hrvatskoj i Slavoniji, Sbornik zakona i naredaba 1/1914.

33 HR-HDA-79. UOZV, sv. IV-5, br. 23338/1918.; HR-DAVŽ-649. GPV, 3.1.3. Redovni spisi, br. 9605/1920.
} 
zastupnika se je mogao kandidirati državljanin Kraljevstva, zavičajnik i stanovnik gradske općine s navršenih 30 godina i aktivnim izbornim pravom. ${ }^{34}$

U nadležnost gradskoga zastupstva pripadali su poslovi iz samoupravnoga djelokruga općine: donošenje statuta, upravljanje gradskom imovinom i kontrola gradskih financija, donošenje proračuna gradske općine i zaklada i zavoda pod gradskom upravom, sklapanje zakupnih i najamnih ugovora, određivanje nameta, uzimanje zajmova, sistematizacija radnih mjesta, imenovanje službenika, dodjela zavičajnoga statusa, briga o javnoj sigurnosti, skrb o zdravlju i zadovoljenju socijalnih potreba stanovništva i dr. U nekim od poslova (donošenje i izmjena statuta, sistematizacija radnih mjesta i određivanje plaća, imovinsko-pravni poslovi iznad 6.000 forinti vrijednosti, donošenje proračuna i odobrenje rashoda, određivanje općinskih daća i sklapanje zakupnih i najamnih ugovora) zastupstvo nije imalo punu autonomiju te je pojedine zaključke bilo dužno dostavljati na odobrenje ZV-u posredstvom županijske oblasti. ${ }^{35}$

Gradsko je zastupstvo Varaždina »iz važnih razloga« mogla raspustiti Zemaljska vlada, od 1921. Pokrajinska uprava za Hrvatsku i Slavoniju, od 1924. veliki župan Zagrebačke oblasti, odnosno Banska uprava od 1929., te postaviti svojega povjerenika, koji je upravljao gradom do novih izbora. U slučaju raspuštanja zastupstva novi su izbori trebali biti raspisani u roku tri mjeseca, no navedena odredba u pravilu nije poštivana, što je pogodovalo vladajućim strukturama da na čelnim pozicijama što dulje zadrže osobu od povjerenja spremnu provoditi vladinu politiku. ${ }^{36}$

Stupanjem na snagu ZGO-a 1934. gradsko zastupstvo mijenja naziv u gradsko vijeće, zastupnici u vijećnike, a načelnik u predsjednika gradske općine. ${ }^{37}$ Zakonom je propisano, ali ne i realizirano, da se u gradovima od 10.000 do 20.000 stanovnika (gradska općina Varaždin imala je 1931. godine 14.612 stanovnika) ${ }^{38}$ gradsko vijeće sastoji od 36 vijećnika, od kojih predsjednika i dvije trećine (24 vijećnika) izabiru birači na javnim izborima, a jednu trećinu (12 vijećnika) imenuje ban. Mandat gradskoga vijeća trajao je četiri godine. Na čelu vijeća nalazio se je predsjednik, koji je sukladno zakonu trebao biti biran na gradskim izborima kao istaknuti kandidat pobjedničke liste. Predsjednik je pripremao i provodio odluke gradskoga vijeća, upravljao administracijom grada i poslovima gradske imovine, nadzirao rad službenika i gradskih ustanova i poduzeća sa zasebnom upravom te obavljao sve poslove državne uprave u nadležnosti grada.

\footnotetext{
34 Uredba o izboru gradskih zastupstva za gradove Hrvatske i Slavonije, Zbornik zakona i naredaba valjanih za Hrvatsku i Slavoniju 68/1919, čl. 3.

35 HR-HDA-137. PU, Odjeljenje za unutarnje poslove, sv. III-1, br. 15101/1923.

36 Grgić, “Općinske uprave u vrijeme šestosiječanjske diktature," str. 96-98.

37 Zakon o gradskim opštinama, Zbirka zakona i uredaba 177/1934, čl. 21.

38 Rafael Landikušić, Priručnik o političkoj i sudbenoj podjeli Savske banovine (Zagreb: vlastita naklada, 1938), str. 175.
} 


\subsubsection{Razdoblje 1914.-1920.}

Zastupstvo Varaždina koje je predsjedalo gradskom općinom tijekom političko-društvenoga prevrata 1918. godine izabrano je 16., 17. i 18. ožujka 1914. na posljednjim gradskim izborima u Austro-Ugarskoj Monarhiji. Od trideset zastupnika čak su dvadeset šestorica pripadala zajedničkoj koaliciji tzv. Nezavisnoga građanstva, što je bila pretpostavka za relativno skladan rad zastupstva. Dužnost gradskoga načelnika obnašao je od konstituirajuće sjednice održane 28. ožujka 1914. Pero Magdić (usp. Tablica 1), a dužnost podnačelnika Josip Vanek.

Tijekom razdoblja 1914.-1918. šestorica su zastupnika prekinula (ili svojevoljno ili uslijed smrti) svoje mandate, te je grad Varaždin ušao u novu državu s 24 zastupnika. Uspostavom Kraljevstva SHS dolazi do izrazitije polarizacije političkoga života, pa tako i do raskola dotadašnjih istomišljenika iz vladajuće koalicije, uglavnom na centraliste i federaliste: centralistički orijentiran ogranak Demokratske stranke (DS) za Varaždin i okolicu osnovan je 24. veljače 1919., ${ }^{39}$ a opozicijski Demokratski građanski krug 17. veljače 1919. godine. ${ }^{40}$

Petorica zastupnika Demokratske stranke položili su 8. lipnja 1919. godine zastupstvu Grada Varaždina svoje mandate jer su »birani po zakonu stvorenom pod erom zle uspomene bana Khuena, te što su na to pozvani od varaždinske organizacije DS-a «. ${ }^{41}$ Gradsko zastupstvo nije prihvatilo njihove ostavke jer su se ostavke mogle podnijeti prije isteka razdoblja od šest godina samo iz osobito važnoga razloga. ${ }^{42}$ Usprkos odluci pet zastupnika DS-a nije se odazivalo na sjednice gradskoga zastupstva, iako su u zapisnicima sjednica redovito evidentirani kao »neispričano odsutni«. Time je zastupstvo i nadalje, barem na papiru, nastavilo rad s dvadeset i četvero zastupnika. ${ }^{43}$

Zastupstvo grada Varaždina ipak se nije dugo održalo jer su naredbom bana od 24. studenoga 1919. br. 13353 Pr. o raspustu gradskih zastupstva i općinskih odbora i sukladno Uredbi o izboru gradskih zastupstva raspuštena u Hrvatskoj i Slavoniji sva gradska i općinska zastupstva. ${ }^{44} \mathrm{Na}$ mjesto dotadašnjega načelnika Varaždina postavljen je 28. studenoga 1919. županijski tajnik Stjepan Šikić. ${ }^{45}$

\footnotetext{
39 Sugrađani!, Volja naroda 2, br. 9 (27. veljače 1919): str. 1.

40 Osnutak građanskog demokratskog kluba, Slobodni gradanin 1, br. 1 (29. ožujka 1919): str. 1.

41 Odstup gradskih zastupnika, Volja naroda 2, br. 24 (13. lipnja 1919): str. 4.

42 HR-DAVŽ-649. GPV, 1.1. Zapisnici sjednica Gradskoga zastupstva, zapisnik od 25. lipnja 1919.

${ }^{43}$ HR-DAVŽ-649. GPV, 2.3. Prezidijalni spisi, izvještaj vladina povjerenika Šikića u kojem stoji da je broj gradskih zastupnika $s$ trideset spao na dvadeset i četvero, od kojih su šestorica pristaše JDS-a, a ostalih osamnaest Građanskoga demokratskoga kluba, br. 9/1920.

44 HR-DAVŽ-649. GPV, 2.4. Povjerljivi spisi, br. 83/1919.

45 HR-HDA-102. VŽ, 2.4. Povjerljivi spisi, br. 2769/1919.
} 
Šikić se je nakon nekoliko mjeseci iz zdravstvenih razloga zahvalio na dužnosti, te je ban 15. ožujka 1920. za novoga vladina povjerenika postavio »iskusnog i pouzdanog činovnika " Matu Furlana. ${ }^{46}$ Novi je povjerenik obnašao dužnost od primopredaje 18. ožujka 1920. do 7. lipnja 1920. godine, kada je po provedenim izborima imenovano novo zastupstvo i izabran novi načelnik.

\subsubsection{Razdoblje 1920.-1925.}

Sukladno ZGO-u iz 1895. i Uredbi o izboru gradskih zastupstva, u Varaždinu su 27. ožujka 1920. provedeni prvi izbori za gradsko zastupstvo od uspostave Kraljevstva SHS. Od trideset novoizabranih zastupnika sedamnaest je dolazilo s liste Nezavisnoga građanstva, ${ }^{47}$ a ostali su bili članovi DS-a i Socijaldemokratske stranke. ${ }^{48}$ Na konstituirajućoj sjednici 7. travnja 1920. za načelnika je izabran Vjekoslav Podgajski.

Iako je zastupstvo bilo takoreći podijeljeno u dva politička bloka, u početku je rad tekao manje-više nesmetano zahvaljujući blagoj prevlasti Nezavisnoga građanstva, iz čijih je redova dolazio i načelnik. No ta neznatna premoć bila je kratkoga vijeka: tijekom vremena pojavili su se sukobi zastupnika Nezavisnoga građanstva $s$ načelnikom i on je u očima dotadašnjih istomišljenika sve više gubio politički kredibilitet, ${ }^{49}$ a polovicom 1922., zbog suradnje s DS-om, potpuno ga je izgubio. ${ }^{50}$

Sukladno ZGO-u iz 1895., nakon tri godine, 19. prosinca 1923. iz gradskoga je zastupstva istupila polovica odbornika izabranih ždrijebom. Na izborima za novih petnaest mandatara 27. siječnja 1924. godine izabrano je deset predstavnika Hrvatskoga bloka (HB), tri DS-a i dva Nezavisnoga građanstva. ${ }^{51}$

Ubrzo nakon izbora, u novom sastavu gradskoga zastupstva stranačka razmimoilaženja postala su sve očitija i konflikti sve naglašeniji, te je Podgajski potaknut učestalim medijskim i zastupničkim provokacijama dao ostavku na mjesto načelnika 11. lipnja 1924. godine. ${ }^{52}$ Narednu sjednicu, na kojoj je trebalo raspraviti ostavku načelnika, bojkotiralo je 16 zastupnika Hrvatskoga bloka pa

\footnotetext{
46 HR-HDA-78. PRZV, sv. 6-14, br. 10096/1919., br. 4512/1920. Usp. HR-DAVŽ-649. GPV, 2.4. Povjerljivi spisi, br. 17/1920.

47 Neodvisnu građansku stranku činila je koalicija Hrvatske zajednice, Hrvatske stranke prava i Hrvatske pučke stranke.

48 Rezultati glasovanja, Slobodni građanin 2, br. 27 (31. ožujka 1920): str. 2.

49 Da se razumijemo!, Narodno jedinstvo 2, br. 1 (7. siječnja 1922): str. 3.

50 Režim Podgajski mora se što dulje održati!, Narodno jedinstvo 2, br. 24 (17. lipnja 1922): str. 4.

51 HR-DAVŽ-649. GPV, 6.4.2. Izbori gradskih zastupnika, spis br. 786/1924.

52 Skupština gradskog zastupstva, Naše pravice 1, br. 1 (3. srpnja 1924): str. 3-4.
} 
im je zastupstvo ukinulo mandate..$^{53}$ Kako je tim činom gradsko zastupstvo ostalo bez polovice zastupnika, veliki je župan rješenjem br. 16972 od 6. prosinca 1924., radi osiguranja redovne uprave grada, postavio pristašu DS- $\mathrm{a}^{54}$ Dragutina Perka privremenim upraviteljem, ${ }^{55}$ koji je 10. prosinca 1924. preuzeo dužnost. ${ }^{56} \mathrm{Grad}-$ sko zastupstvo, iako krnje, nije raspuštano, ali nije sazivano niti je donosilo odluke. Nastavilo je djelovati isključivo na papiru, a sve je odluke važne za grad donosio privremeni upravitelj. ${ }^{57}$

Nakon osam mjeseci upravitelj Perko predao je molbu za razrješenjem dužnosti te je veliki župan naredbom br. 62157 od 6. kolovoza 1925. upravu grada 11. kolovoza $1925 .{ }^{58}$ predao $»$ najstarijem perovodnom činovniku gradskog poglavarstva", simpatizeru DS-a i Radikalne stranke, ${ }^{59}$ Feliksu Jakominiju, ${ }^{60}$ koji je dužnost gradskoga načelnika obnašao naredna tri mjeseca do održavanja novih gradskih izbora.

Takvim spletom okolnosti mandat prvoga varaždinskoga gradskoga zastupstva u Kraljevstvu, odnosno Kraljevini SHS sa šest je godina skraćen na četiri godine i sedam mjeseci. Nakon posljednje skupštine održane 25. studenoga 1924. gradskom je općinom Varaždin upravljao jedan vladin komesar i jedan službenik gradskoga poglavarstva.

\subsubsection{Razdoblje 1925.-1927.}

Drugi mandat gradskoga zastupstva izabran je 25. listopada 1925. godine. $\mathrm{Na}$ izborima se je kandidiralo pet stranaka, od kojih je najviše, jedanaest glasova dobio Hrvatski izborni blok, ${ }^{61}$ zatim devet Hrvatska seljačka stranka (HSS), pet Samostalna demokratska stranka (SDS), tri Narodna radikalna stranka (NRS) i dva lista Privrednika Hrvatskoga nezavisnoga građanstva. ${ }^{62}$ Iako se je činilo da će relativno srodne federalističke stranke HB i HSS udružiti snage i voditi grad sa svojih 20 mandata, stvarnost je demantirala očekivanja koaliranjem HSS-a s Radikalima. Na taj su način obje najjače političke opcije imale po 11 glasova, što

\footnotetext{
53 HR-DAVŽ-649. GPV, 1.1. Zapisnici sjednica Gradskoga zastupstva, zapisnik od 25. studenoga 1924., čl. 47.

54 Vinko Podgajski i privrednici, Narodno jedinstvo 4, br. 23 (22. listopada 1925): str. 2.

55 HR-DAVŽ-649. GPV, 2.4. Povjerljivi spisi, br. 31/1924.

56 HR-DAVŽ-649. GPV, 2.4. Povjerljivi spisi, br. 32/1924.

57 Bespravlje na gradskoj općini, Narodno jedinstvo 4, br. 1 (21. svibnja 1925): str. 2.

58 HR-DAVŽ-649. GPV, 2.4. Povjerljivi spisi, br. 62/1925.

59 Varaždinska "radikalija" na djelu, Narodno jedinstvo 4, br. 18 (7. rujna 1925): str. 1-2.

60 HR-DAVŽ-649. GPV, 2.4. Povjerljivi spisi, br. 61/1925.

${ }^{61}$ Gradski izbori u Varaždinu, Narodno jedinstvo 4, br. 24 (29. listopada 1925): str. 1. Hrvatski izborni blok 1925. godine činila je zajednička lista Hrvatske zajednice i Hrvatske stranke prava.

62 HR-DAVŽ-649. GPV, 6.4.2. Izbori gradskih zastupnika, br. 8651/1925.
} 
je već na početku ukazalo na nemogućnost skladnoga i kontinuiranoga upravljanja gradom. Polarizirano političko ozračje došlo je do izražaja već na konstituirajućoj sjednici 9. studenoga 1925., kada zastupstvo nije postignulo dogovor o izboru načelnika. Izbor je razriješen na narednoj sjednici 13. studenoga, kada je novi načelnik postao Ivan Kovačević iz Hrvatskoga izbornoga bloka. ${ }^{63}$

Nakon godinu dana, zbog neizglasavanja proračuna došlo je do pada gradskoga zastupstva na skupštini održanoj 20. prosinca 1926., te je ministar unutrašnjih poslova donio 4. siječnja 1927. rješenje o raspuštanju zastupstva i razrješenju dužnosti načelnika. ${ }^{64}$ Tako je drugi sastav gradskoga zastupstva ugašen za svega jednu godinu i mjesec dana, a njegovu je ulogu preuzeo postavljeni vladin komesar, radikal Dušan Dragojlović, penzionirani žandarski potpukovnik.

\subsubsection{Razdoblje 1927.-1928.}

Izbori za treći mandat varaždinskoga gradskoga zastupstva održani su 15. svibnja 1927. naredbom ministra unutrašnjih poslova br. 21 od 4. siječnja 1927. i dopisa velikoga župana br. 1619 od 12. siječnja 1927. godine. U gradsko je zastupstvo izabrano petnaest predstavnika Izbornoga bloka Hrvatskih udruženih stranaka, ${ }^{65}$ devet Građanske demokracije (SDS), tri Narodne radikalne stranke, jednoga Socijalističke partije Hrvatske i dvoje radićevskih disidenata. Politička podjela na dva bloka (s jedne strane Hrvatskih udruženih stranaka i druge SDS-a s udruženim predstavnicima ostalih zastupljenih opcija) došla je do izražaja već na konstituirajućoj skupštini održanoj 8. lipnja 1927. godine. Naime, prilikom izbora gradskoga načelnika bezuspješnim se je pokazao čak i izbor kandidacijskoga odbora, tako da do izbora načelnika nije ni došlo. Poglavarstvo je velikomu županu dostavilo zapisnik skupštine zajedno s izvještajem u kojem je navedeno da novoizabrano zastupstvo, $s$ obzirom na konstelaciju, nije sposobno za rad, ${ }^{66}$ te je gradom nastavio upravljati postavljeni komesar Dragojlović.

\subsubsection{Razdoblje 1928.-1929.}

Naredbom ministra unutrašnjih poslova br. 2612 od 5. travnja 1928. održani su 15. srpnja 1928. četvrti, ujedno i posljednji izbori varaždinskoga gradskoga zastupstva. Sva naredna zastupstva i načelnici imenovani su odlukom oblasnoga velikoga župana, odnosno bana. Na izborima je dvadeset mandata osvojila

\footnotetext{
${ }^{63}$ HR-DAVŽ-649. GPV, 1.1. Zapisnici sjednica Gradskoga zastupstva, zapisnik od 13. studenoga 1925.

64 HR-DAVŽ-649. GPV, 3.1.3. Redovni spisi, br. 391/1927.

65 Nakon gradskih izbora, Narodno jedinstvo 6, br. 20 (19. svibnja 1927): str. 1. Izborni blok Hrvatskih udruženih stranaka održao je izbornu skupštinu pred izbore, 13. svibnja 1927. godine. U blok su ušli Hrvatska federalistička seljačka stranka, Hrvatska pučka stranka, Hrvatska stranka prava i HSS.

${ }^{66}$ HR-DAVŽ-649. GPV, 3.1.3. Redovni spisi, br. 5875/1927.
} 
Seljačko-demokratska koalicija, od toga Samostalna demokratska stranka (SDS) jedanaest, a Hrvatska seljačka stranka osam mandata. Hrvatski je blok kao opozicija osvojio osam zastupnika, a tri su ostale stranke (radikali, klerikalci i radićevski disidenti) osvojile svaka po jednoga zastupnika. ${ }^{67} \mathrm{Na}$ konstituirajućoj sjednici 28. srpnja 1928. za načelnika je izbran Hinko Krizman, predstavnik SDS-a. Primopredaja između njega i Dragojlovića obavljena je dva dana kasnije, 30. srpnja 1928. ${ }^{68}$ čime je završila čak devetnaestomjesečna uprava komesara. Na Dragojlovićevu upravu kritički je reagiralo novoizabrano gradsko zastupstvo zbog »kršenja zakonom zajamčene gradske autonomije postavljanjem i podržavanjem vladinog komesarijata koji je pored izabranog gradskog zastupstva trajao preko osamnaest mjeseci ${ }^{69}{ }^{6}$

Pet mjeseci po konstituiranju gradskoga zastupstva nastupilo je razdoblje Šestosiječanjske diktature, kojom je ukinut Ustav i doneseni zakoni koji su uzdrmali ionako "klimavu" autonomiju gradske samouprave. Iako je 6. siječnja 1929. donesen Zakon o izmeni Zakona o opštinama i oblasnim samoupravama, kojim su trebale biti razriješene sve općinske uprave, krajem siječnja još se je uvijek u medijima spekuliralo o nastavku djelovanja izabranoga varaždinskoga gradskoga zastupstva. ${ }^{70} \mathrm{No}$, uvođenje diktature zaoštrilo je postojeće i rasplamsalo nove stranačke nesuglasice te je načelnik Krizman bio prisiljen predati ostavku. ${ }^{71}$ Rješenjem Pov. 3304/1929. od 8. ožujka 1929. veliki je župan razriješio Krizmana dužnosti načelnika, poslove gradskoga poglavarstva predao šefu magistrata Stjepanu Novakoviću (primopredaja izvršena 12. ožujka 1929.), a poslove gradskoga zastupstva gradskomu podnačelniku Ferdi Kalabaru. ${ }^{72}$ Gradsko je zastupstvo raspušteno 18. ožujka 1929. rješenjem velikoga župana br. 4075. Pov. ${ }^{73}$

\subsubsection{Razdoblje 1929.-1930.}

Istim rješenjem postavljeno je novo gradsko zastupstvo, a na mjesto gradskoga načelnika Viktor Plazzeriano, dotadašnji član Samostalne demokratske stranke (SDS), ujedno "inžinjer koji uživa općenite simpatije u građanstvu«. ${ }^{74}$

67 Gradski izbori u Varaždinu, Narodno jedinstvo 7, br. 29 (19. srpnja 1928): str. 3.

68 HR-DAVŽ-649. GPV, 2.3. Povjerljivi spisi, br. 13/1928.

69 HR-DAVŽ-649. GPV, 1.1. Zapisnici sjednica Gradskoga zastupstva, zaključak od 22. kolovoza 1928., prijedlog izvan dnevnoga reda.

70 U upravi grada Varaždina, Narodno jedinstvo 8, br. 4 (24. siječnja 1929): str. 2.

71 HR-DAVŽ-649. GPV, 2.3. Povjerljivi spisi, br. 15/1929.

72 HR-DAVŽ-649. GPV, 2.3. Povjerljivi spisi, Rješenje Velikog Župana Zagrebačke oblasti br. 3304 Pov. od 8. ožujka 1929., br. 20/1929.

73 HR-DAVŽ-649. GPV, 6.4.2. Izbori gradskih zastupnika, Oglas o raspuštanju gradskoga zastupstva izabranog 15. srpnja 1928. i postavljanju uprave Općine grada Varaždina, br. 3681/1929.

74 Nova gradska uprava, Narodno jedinstvo 8, br. 12 (1929): str. 1. 
Prva skupština novoga zastupstva održana je 26. ožujka 1929., a primopredaja poslova između Novakovića i Plazzeriana obavljena je 27. ožujka 1929. godine. Od 30 novih gradskih zastupnika, 21 je obnašao mandat u prošlom sastavu, a ostali su izabrani među kandidatima s izbornih lista od 15. srpnja 1928. godine. Šestosiječanjskom diktaturom zabranjen je rad političkih stranaka, svih oporbenih i režimskih političkih organizacija. ${ }^{75}$ Iako političko opredjeljenje nije isticano, analiza pokazuje da su imenovani zastupnici u prvoj godini diktature većinom dolazili iz dotadašnjih stranaka: HSS-a, HPS-a, HB-a i SDS-a. Na vlasti su uglavnom zadržane osobe spremne baviti se isključivo komunalnim, a ne političkim pitanjima. ${ }^{76}$

Već nakon godinu i dva mjeseca cijelo gradsko zastupstvo raspušteno je rješenjem bana br. 42801/II od 24. travnja 1930. na temelju Zakona o izmeni Zakona o opštinama i oblasnim samoupravama.

\subsubsection{Razdoblje 1930.-1936.}

Istim banskim rješenjem o raspuštanju dotadašnjega zastupstva imenovano je novo, koje je 2. svibnja 1930. položilo zakletvu. U novom je zastupstvu djelovalo četrnaest dotadašnjih i šesnaest novoimenovanih zastupnika, od kojih su devetorica prvi put postali zastupnici, a ostali su bili izabrani na posljednjim izborima 1928. godine ili su obnašali dužnost u nekom od prošlih mandata. ${ }^{77} \mathrm{Za} \mathrm{grad-}$ skoga je načelnika ponovno izabran Plazzeriano, a za podnačelnika Josip Vanek.

Načelnik Plazzeriano obavljao je dužnost manje od godine dana, kada je rješenjem Banske uprave od 3. travnja 1931. razriješen, ${ }^{78}$ a na njegovo je mjesto imenovan Dragutin Perko, koji je prilikom posjeta bana Ive Perovića Varaždinu 30. ožujka 1931. izrazio spremnost raditi na promicanju režimskih ciljeva. ${ }^{79}$ Primopredaja vlasti između dotadašnjega i novoimenovanoga načelnika obavljena je 4. travnja 1931. godine.

$S$ obzirom na to da je nakon pola godine Perko izabran poslanikom na prvim parlamentarnim izborima za Narodnu skupštinu, Banska ga je uprava razriješila rješenjem br. Pov. 36843-II od 23. prosinca 1931. te je za vršitelja dužnosti načelnika postavila gradskoga vijećnika Stjepana Novakovića, koji je 7. siječnja 1932. položio zakletvu.

Bosiljka Janjatović, Politički teror u Hrvatskoj 1918.-1935. (Zagreb: Hrvatski institut za povijest, 2002), str. 43.

76 Grgić, "Općinske uprave u vrijeme šestosiječanjske diktature," str. 97.

77 Novo gradsko zastupstvo, Varaždinske novosti 1, br. 21 (1. svibnja 1930): str. 1.

78 HR-DAVŽ-649. GPV, 2.4. Povjerljivi spisi, br. 12/1931.

79 Dolazak bana u Varaždin, Varaždinske novosti 2, br. 69 (4. travnja 1931): str. 1. 
Tijekom diktature zastupnici su se učestalo izmjenjivali, tako da je kroz pet godina mandata skoro u potpunosti izmijenjen sastav gradskoga zastupstva. Pojedini su se zastupnici zahvalili na časti, a pojedini su bili smijenjeni rješenjem Banske uprave. Velike smjene zastupnika odvile su se u dva navrata: 3. srpnja 1931., kada je rješenjem Banske uprave od 23. lipnja 1931. br. Pov. II. 15877 postavljeno petnaest novih zastupnika koji su zamijenili šestoricu zastupnika koji su se zahvalili na časti i devetoricu koji su smijenjeni s dužnosti, te 28. prosinca 1931., kada je rješenjem Banske uprave br. Pov. II. 36386 postavljeno osam novih zastupnika i novi podnačelnik Oskar Pulgram. Od uspostave diktature 1929. provođena je stroga kontrola Banske uprave nad djelovanjem i sastavom zastupstva. Čak je i svaka molba za razrješenjem dužnosti strogo kontrolirana. Molba je upućivana na nadležnost Banskoj upravi zajedno s popratnim izvještajem o razlozima koji su naveli pojedince na podnošenje ostavke. ${ }^{80}$ Prilikom predlaganja novih zastupnika načelnik je trebao istaknuti njihovu bivšu političku pripadnosti te paziti da je riječ o ispravnim građanima i uglednim osobama potpuno odanim režimu. ${ }^{81}$

Na sjednici 2. kolovoza 1935. na časti su se zahvalili Novaković, novi narodni poslanik ${ }^{82}$ i potpredsjednik Pulgram. Banska je uprava 12. kolovoza uvažila predsjednikovu ostavku, a vršiteljem dužnosti predsjednika imenovala Pulgrama. ${ }^{83}$ Primopredaja poslova dotadašnjega na novoga vršitelja dužnosti bila je 20. kolovoza 1935 . godine. ${ }^{84}$

Jenjavanjem diktature i obnovom političko-stranačkoga života, nakon parlamentarnih izbora 1935. ${ }^{85}$ i u gradskom zastupstvu Varaždina budio se je opozicijski duh. Na sjednici 2. kolovoza 1935. 13 je zastupnika predložilo da se ministru unutrašnjih poslova i banu uputi molba za raspuštanjem staroga, od režima postavljenoga vijeća, i raspisivanjem izbora za nove gradske vijećnike. ${ }^{86}$ Navedeni prijedlog stavljen je na dnevni red naredne sjednice 28. listopada 1935. godine. Kako se nije skupio dovoljan broj vijećnika, sjednica nije održana ${ }^{87}$ te je Pulgram obavijestio Bansku upravu da je nekolicina vijećnika, koji su na pret-

\footnotetext{
80 HR-DAVŽ-649. GPV, 2.4. Povjerljivi spisi, br. 29/1930.

81 HR-DAVŽ-649. GPV, 2.4. Povjerljivi spisi, okružnica Banske uprave o izmjenama općinskih odbora, br. 7/1931.

82 Stjepan Novaković izabran je na drugim izborima za Narodnu skupštinu 5. svibnja 1935. kao pripadnik Jugoslavenske narodne stranke.

83 HR-DAVŽ-649. GPV, 2.4. Povjerljivi spisi, okružnica Banske uprave, upravno odjeljenje Pov. br. 3537-II-1935., br. 120/1935.

84 HR-DAVŽ-649. GPV, 2.4. Povjerljivi spisi, zapisnik o primopredaji, br. 120/1935.

85 Vojak, "Političko-upravne prilike," str. 128.

86 HR-DAVŽ-649. GPV, 1.1. Zapisnici sjednica Gradskoga zastupstva, zapisnik od 2. kolovoza 1935. prijedlozi izvan dnevnog reda, točka 5.

87 HR-DAVŽ-649. GPV, 1.1. Zapisnici sjednica Gradskoga zastupstva, zapisnik od 28. listopada 1935.
} 
hodnoj skupštini predložili raspuštanje gradskoga vijeća, bojkotirala sjednicu. ${ }^{88}$ Napomenuo je da ne namjerava sazivati novu sjednicu te kako bi bilo najpodesnije provesti smjene petnaestorice spornih vijećnika i na njihovo mjesto imenovati nove. Konkretan odgovor stigao je tek nakon četiri mjeseca: rješenjem bana Savske banovine od 26. veljače 1936. pov. br. 1250-II službeno je ugašen mandat vijeća i vršitelja dužnosti predsjednika. ${ }^{89}$

\subsubsection{Razdoblje 1936.-1938.}

Istim rješenjem postavljen je za predsjednika gradske općine Vladimir Milković, odvjetnik iz Varaždina, za potpredsjednika Marcel Matanović i imenovano novo vijeće. Konstituirajuća sjednica održana je 5. ožujka 1936., kada je obavljena i primopredaja vlasti. ${ }^{90}$ Milković je u svojem uvodnom govoru istaknuo da je na nagovor bana prihvatio dužnosti predsjednika gradske općine "kako bi se depolitizirala uprava grada Varaždina, došlo do ozdravljenja društvenih prilika i time pripremio teren za slobodne izbore «. ${ }^{91}$ Dakle, pozivajući se na Zakon o izmeni Zakona o opštinama i oblasnim samoupravama i na odredbu ZGO-a iz 1934., sukladno kojoj se "gradski organi određuju po dosadašnjim zakonima dok se ne izaberu gradska vijeća po novom zakonu«, ${ }^{92}$ gradska je općina Varaždin ponovno dobila postavljenu režimsku vlast sastavljenu od 30 vijećnika. $S$ obzirom na to da je gradsko vijeće postavljano, a ne birano, nije se primjenjivala ni odredba ZGO-a iz 1934., sukladno kojoj je u vijeću trebalo sjediti 36 vijećnika.

Kada je početkom 1938. zbog bolesti Milković bio primoran podnijeti ostavku, poslove vršitelja dužnosti predsjednika 19. siječnja 1938. preuzeo je prvi gradski vijećnik Hubert Wanderer. ${ }^{93}$ Odlaskom predsjednika i 17 se je vijećnika 28. siječnja 1938. zahvalilo na časti. Ban je naložio da mu ne šalju ostavke jer ih, s obzirom na zadovoljstvo sastavom gradskoga vijeća, nije spreman prihvatiti i da prema planu nastave raditi. ${ }^{94}$ Ipak, gradsko se vijeće više nije sastalo te je ban 11 . ožujka rješenjem Pov-II-1400/1938. razriješio dužnosti dotadašnjega predsjednika i vijećnike. ${ }^{95}$

\footnotetext{
88 HR-DAVŽ-649. GPV, 2.4. Povjerljivi spisi, br. 131/1935.

${ }^{89}$ HR-DAVŽ-649. GPV, 2.4. Povjerljivi spisi, br. 13/1936.

90 HR-DAVŽ-649. GPV, 2.4. Povjerljivi spisi, br. 14/1936.

91 HR-DAVŽ-649. GPV, 1.1. Zapisnici sjednica Gradskoga zastupstva, zapisnik od 5. ožujka 1936.

92 Zakon o gradskim opštinama, Zbirka zakona i uredaba 177/1934, čl. 147.

93 HR-DAVŽ-649. GPV, 2.4. Povjerljivi spisi, br. 16/1938.

94 HR-DAVŽ-649. GPV, 2.4. Povjerljivi spisi, izvještaj H. Wanderera o razgovoru s banom, br. 24/1938.

${ }^{9}$ HR-DAVŽ-649. GPV, 2.4. Povjerljivi spisi, br. 45/1938.
} 


\subsubsection{Razdoblje 1938.-1939.}

Istim rješenjem od 11. ožujka 1938. ban je postavio novo gradsko vijeće na čelu s predsjednikom Dragutinom Perkom i potpredsjednikom Miroslavom Posmodijem. Konstituirajuća sjednica održana je 16. ožujka 1938., isti dan kada je bila primopredaja između vršitelja dužnosti i novoimenovanoga predsjednika. ${ }^{96}$

No, već nakon osam mjeseci, odlukom Banske uprave br. Pov-II-6772/ 1938 od 19. studenoga 1938. provedena je nova rekonstrukcija vijeća, kojom je razriješen dužnosti gradski potpredsjednik i šesnaest vijećnika. Odmah po rekonstrukciji vijeća Varaždinske novosti pisale su kako je na pomolu moguća solidarna inicijativa između razriješenih vijećnika i onih ostavljenih na dužnosti. ${ }^{97}$ Upravo to se je i obistinilo. Naime, "nerazriješeni" vijećnici uputili su 2. prosinca 1938. Banskoj upravi ostavku kojom se solidariziraju sa »smijenjenim drugovima, koji su u zajednici s njima radili samo u korist grada i radi kojih su se i oni vijećničke dužnosti prihvatili« ${ }^{98}$ Nakon što je uslijedilo još nekoliko pojedinačnih ostavki, predsjednik Perko izvijestio je Bansku upravu da je gradsko vijeće ostalo bez osamnaest vijećnika te da nema kvorum za donošenje pravovaljanih odluka.

Uspostavom Banovine Hrvatske ban je 30. kolovoza 1939. rješenjem Pov-II-3809/1939. razriješio dužnosti predsjednika Perka i cijelo gradsko vijeće, a poslove gradske općine privremeno povjerio najstarijemu službeniku pravniku Mirku Hikecu. ${ }^{99}$ Primopredaja poslova obavljena je narednoga dana 31. kolovoza 1939. godine.

\subsubsection{Razdoblje 1939.-1940.}

Dana 3. listopada 1939. ban je dekretom br. 21434-I-1939. za povjerenika gradske općine postavio suca Okružnoga suda Mirka Vučkovića, koji je, sudeći prema pisanju lista Hrvatsko jedinstvo, smatran sretnim rješenjem i konačnim utjelovljenjem "glasa hrvatskog naroda « i HSS-a. ${ }^{100}$ Vučković je 6. listopada 1939. položio zakletvu i preuzeo poslove. Postavljen je sukladno čl. 142 ZGO-a iz 1934., kojim je propisano da nadzorna vlast određuje povjerenika do uvođenja u dužnost novoga gradskoga vijeća. Povjerenik je gradom upravljao bez gradskoga vijeća, obavljao tekuće poslove i samostalno donosio dio odluka iz kompetencije vijeća, izuzev onih koje su se odnosile na zaduženje, otuđenje imovine, uvođenje novih trošarina i postavljanje službenika. ${ }^{101}$ Sve njegove odluke kontro-

\footnotetext{
96 HR-DAVŽ-649. GPV, 2.4. Povjerljivi spisi, br. 45/1938.

97 Gradske vijesti (Prve uzbune), Varaždinske novosti 9, br. 469 (24. studenoga 1938): str. 4.

98 HR-DAVŽ-649. GPV, 2.4. Povjerljivi spisi, br. 273/1938.

99 HR-DAVŽ-649. GPV, 2.4. Povjerljivi spisi, br. 140/1939.

${ }^{100}$ Glas hrvatskog građanstva prigodom imenovanja povjerenikom g. M. Vučkovića, Hrvatsko jedinstvo 3, br. 105 (14. listopada 1939): str. 4.

${ }^{101}$ Zakon o gradskim opštinama, Zbirka zakona i uredaba 177/1934, čl. 142.
} 
lirao je Odjel za unutrašnje poslove Banske vlasti, Odsjek za samouprave zadužen za nadzor gradske samouprave. ${ }^{102}$

Dana 10. travnja 1940. Banska je vlast okružnicom Pov. 228-I-1940. pozvala sve gradske povjerenike da predlože buduće vijećnike, ${ }^{103}$ uz napomenu da broj zastupnika grada Varaždina ostaje trideset, sukladno odredbama koje su bile na snazi prije ZGO-a iz 1934. godine. ${ }^{104}$ Pri odabiru vijećnika trebalo je voditi računa o političkom raspoloženju građanstva i tadašnjim prilikama te je povjerenik 3. svibnja 1940., sukladno prijedlogu mjesne organizacije HSS-a, za načelnika predložio sebe, a za podnačelnika Ljudevita Bana. ${ }^{105}$

\subsubsection{Razdoblje 1940.-1941.}

Rješenjem br. 50670-I-2-1940. od 7. svibnja 1940. ban je za načelnika postavio Vučkovića, za podnačelnika Bana i dvadeset osam novih vijećnika koji su položili zakletvu 15. svibnja. ${ }^{106} \mathrm{Na}$ sjednici je istaknuto kako vanjskopolitičke prilike nisu povoljne za održavanje izbora, te je za rješavanje neodgodivih samoupravnih poslova nužno postaviti vijeće. ${ }^{107}$

Nakon pet mjeseci Vučković je, zbog sukoba s gradskom organizacijom HSS-a, iz čijih je redova dolazila većina zastupnika, podnio ostavku, koju je Banska vlast prihvatila rješenjem 96503-I-2-1940. od 9. listopada 1940. ${ }^{108}$ Novi vršitelj dužnosti, podnačelnik Ban preuzeo je poslove 11. listopada 1940. godine. ${ }^{109}$

U manje-više nepromijenjenom sastavu s istim vršiteljem dužnosti načelnika zastupstvo je dočekalo travanj 1941. godine. Uspostavom Nezavisne Države Hrvatske razriješeno je gradsko zastupstvo s danom 11. travnja, a ostavku Bana uvažio je 30. travnja 1941. ustaški povjerenik za bivšu Županiju varaždinsku rješenjem br. 540/1041. ${ }^{110}$ Istoga je dana obavljena primopredaja vlasti s dotadašnjega načelnika na novoimenovanoga povjerenika gradske općine Vjekoslava Medvedovića.

\footnotetext{
${ }^{102}$ HR-HDA-157. BHOUP, br. 12894/1940. (kut. 86).

${ }^{103}$ HR-DAVŽ-649. GPV, 2.4. Povjerljivi spisi, br. 37/1940.

${ }^{104}$ HR-DAVŽ-649. GPV, 2.4. Povjerljivi spisi, br. 38/1940.

${ }^{105}$ HR-DAVŽ-649. GPV, 2.4. Povjerljivi spisi, br. 38/1940.

${ }^{106}$ HR-DAVŽ-649. GPV, 1.1. Zapisnici sjednica Gradskoga zastupstva, zapisnik od 15. svibnja 1940.

${ }^{107}$ HR-DAVŽ-649. GPV, 1.1. Zapisnici sjednica Gradskoga zastupstva, zapisnik od 15. svibnja 1940., govor gradskoga zastupnika Tomislava Košića, predsjednika mjesne organizacije HSS-a.

${ }^{108}$ HR-DAVŽ-649. GPV, 1.1. Zapisnici sjednica Gradskoga zastupstva, zapisnik od 15. svibnja 1940., točka 1.

${ }^{109}$ HR-DAVŽ-649. GPV, 1.1. Zapisnici sjednica Gradskoga zastupstva, zapisnik od 15. svibnja 1940., točka 1 .

${ }^{110}$ HR-DAVŽ-649. GPV, 2.4. Povjerljivi spisi, br. 60/1941.
} 
Tablica 1. Pregled načelnika i vladinih povjerenika ${ }^{111}$

\begin{tabular}{|l|l|l|l|l|}
\hline Br. & Razdoblje & $\begin{array}{l}\text { Izabrani } \\
\text { načelnik }\end{array}$ & $\begin{array}{l}\text { Imenovani } \\
\text { načelnik }\end{array}$ & $\begin{array}{l}\text { Vladin } \\
\text { povjerenik }\end{array}$ \\
\hline 1. & $28.3 .1914 .-28.11 .1919$. & Pero Magdić & & \\
\hline 2. & $28.11 .1919 .-18.3 .1920$. & & & Stjepan Šikić \\
\hline 3. & $18.3 .1920 .-7.6 .1920$. & & & Mato Furlan \\
\hline 4. & $7.6 .1920 .-6.12 .1924$. & $\begin{array}{l}\text { Vjenceslav } \\
\text { Podgajski }\end{array}$ & & \\
\hline 5. & $6.12 .1924 .-6.8 .1925$. & & & Dragutin Perko \\
\hline 6. & $6.8 .1925 .-13.11 .1925$. & & & $\begin{array}{l}\text { Feliks } \\
\text { Jakomini }{ }^{12}\end{array}$ \\
\hline 7. & $13.11 .1925 .-4.1 .1927$. & Ivan Kovačević & & \\
\hline 8. & $4.1 .1927-28.7 .1928$. & & & $\begin{array}{l}\text { Dušan } \\
\text { Dragojlović }\end{array}$ \\
\hline 9. & $28.7 .1928 .-8.3 .1929$. & Hinko Krizman & & \\
\hline 10. & $26.3 .1929 .-3.4 .1931$. & & $\begin{array}{l}\text { Viktor } \\
\text { Plazzeriano }\end{array}$ & \\
\hline 11. & $3.4 .1931 .-23.12 .1931$. & & Dragutin Perko & \\
\hline 12. & $7.1 .1932 .-12.8 .1935$. & & $\begin{array}{l}\text { Stjepan } \\
\text { Novaković }\end{array}$ & \\
\hline 13. & $12.8 .1935 .-26.2 .1936$. & & Oskar Pulgram ${ }^{114}$ & \\
\hline 14. & $5.3 .1936 .-19.1 .1938$. & & $\begin{array}{l}\text { Milković } \\
\text { Vladimir }\end{array}$ & \\
\hline 15. & $19.1 .1938 .-11.3 .1938$. & & $\begin{array}{l}\text { Hubert } \\
\text { Wanderer }{ }^{115}\end{array}$ & \\
\hline 16. & $16.3 .1938 .-30.8 .1939$. & & Dragutin Perko & \\
\hline 17. & $6.10 .1939 .-15.5 .1940$. & & Mirko Vučković & \\
\hline 18. & $15.5 .1940 .-9.10 .1940$. & & Ljudevit Ban ${ }^{116}$ & \\
\hline 19. & $9.10 .1940 .-30.4 .1941$. & & & Mirko Vučković \\
\hline
\end{tabular}

\footnotetext{
${ }^{111}$ Kao datum stupanja na dužnost za izabrane i imenovane načelnike uzet je datum polaganja prisege, a za vladine povjerenike datum polaganja prisege ili datum rješenja o postavljanju.

${ }^{112}$ Imenovan je vršiteljem dužnosti.

${ }^{113}$ Imenovan je vršiteljem dužnosti.

${ }^{114}$ Imenovan je vršiteljem dužnosti.

115 Ban je Wandereru naložio »da do daljnjeg vodi agende predsjednika gradske općine«.

${ }^{116}$ Imenovan je vršiteljem dužnosti.
} 


\subsection{Odbori}

Većina predmeta prije dolaska na dnevni red sjednice gradskoga vijeća raspravljana je na sjednici pojedinoga stalnoga odbora. Postojali su stalni savjetodavni odbori gradskoga zastupstva ${ }^{117}$ osnovani sukladno statutu koji su za potrebe zastupstva izrađivali izvješća i prijedloge iz određenih područja. ${ }^{118}$ Njihovi članovi bili su uglavnom gradski zastupnici. ${ }^{119}$ Izuzev savjetodavnih, zastupstvo je sukladno posebnim zakonskim propisima imenovalo odbore sastavljene od vijećnika i građana. ${ }^{120}$ Odbori su birani u pravilu na konstituirajućoj ili prvoj narednoj sjednici zastupstva. Materijal za sjednice odbora pripremali su službenici poglavarstva i dostavljali ga odborima, a odbori su svoje prijedloge slali gradskomu zastupstvu na potvrdu. S obzirom na to da su članovi odbora bili uglavnom vijećnici, većina je prijedloga prihvaćana bez dodatne rasprave. Vijeće je moglo prenijeti odlučivanje o pojedinim poslovima na stalne odbore.

Pojedini su odbori pokrivali dva i više srodnih područja te su ponekad održavali zajedničke sjednice, a ponekad odvojene prema užim interesnim sferama. Zastupstvo je moglo zatražiti da isti predmet pretrese nekoliko odbora na odvojenim ili zajedničkim sjednicama.

Pravno-politički i Gospodarski odbor pokrivali su široko upravno područje i po jednoj sjednici rješavali do 70-ak predmeta. Od 1929. zastupljeni su na sjednicama u većoj mjeri i prijedlozi ostalih odbora, posebno Uboškoga, koji je tijekom tridesetih godina, u vrijeme velike gospodarske krize, po sjednici rješavao i preko 70 molbi. Ovisno o dužnostima odbora varirao je i broj njihovih članova: najviše odbornika, od 15 do 20, nalazilo se je u Pravno-političkom, Gospodarskom i Uboškom odboru, a poneki su odbori imali svega nekoliko članova.

Gradskim statutom iz 1886. propisana su četiri stalna zastupnička odbora (Političko-pravni, Gospodarski, Bolno-uboški i Školski), a ulaskom u Kraljevstvo SHS gradsko je zastupstvo imalo 14 odbora. Promjene društvenih okolnosti, širenje samoupravnoga područja i zakonske regulative tijekom godina utjecali su na promjene broja odbora. Pojedinim su odborima protokom vremena izmijenjeni nazivi, a poneki su podijeljeni na dva odbora, od kojih je svaki pokrivao dio dotadašnjega resora (usp. Tablica 2). Sukladno dostupnim podatcima i uvidu u zapisnike sjednica u nastavku je prikazano područje djelovanja pojedinih odbora.

\footnotetext{
117 Usp. HR-DAVŽ-649. GPV. 1.1. Zapisnici sjednica Gradskoga zastupstva, zapisnik od 15. svibnja 1940., točka 2.

${ }^{118}$ HR-DAVŽ-5. Zbirka statuta, pravilnika, godišnjaka i pojedinih zakonskih akata, 1.1.2.1.2. Statut slobodnoga i kraljevskoga grada Varaždina o unutarnjem uređenju gradske uprave, čl. 61.

${ }^{119}$ HR-DAVŽ-5. Zbirka statuta, pravilnika, godišnjaka i pojedinih zakonskih akata, 1.1.2.1.2. Statut slobodnoga i kraljevskoga grada Varaždina o unutarnjem uređenju gradske uprave, čl. 62-67.

${ }^{120}$ Usp. HR-DAVŽ-649. GPV. 1.1. Zapisnici sjednica Gradskoga zastupstva, zapisnik od 15. svibnja 1940., točka 2.
} 
Bolno-uboški odbor donosio je prijedloge o uzdržavanju zdravstvenih i uboških zavoda, pomoći za bolesne i socijalno ugrožene osobe, pogrebnoj pripomoći, primanju građana u nemoćnicu, odnosno zavod ubogih, pokrivanju bolničkih troškova, donošenju proračuna gradskih uboških zaklada i sl. ${ }^{121}$

Gospodarski je odbor kontrolirao gradske financije i skrbio o upravljanju imovinom, sklapanju zakupnih i najamnih ugovora, nametima i trošarinama, proračunu grada, zaklada i zavoda, uzimanju zajmova i preuzimanju jamstava, oprostu gradskih nameta, pokrivanju potreba poglavarstva i zavoda, aprovizaciji, održavanju sajmova, prihvaćanju neplaniranih troškova u dogovoru s drugim odborima i sl. ${ }^{122}$ Pitanjima stočarstva, osobito licenciranja bikova, bavio se je stočarski odbor, koji je u pojedinim razdobljima djelovao kao samostalni odbor, a povremeno kao dio Gospodarskoga odbora.

Građevni je odbor donosio prijedloge propisa o gradnji, podizanju ili adaptaciji gradskih nekretnina ili objekata javne namjene, pribavljanju zemljišta za gradska gradilišta, dodjeli gradilišta, uređenju grada, urbanističkim planovima (osim kad je to rješavao Regulatorni odbor), razmatrao građevinske ponude i izmjene odobrenih građevinskih projekata i sl. Sukladno Građevinskomu zakonu od 7. lipnja 1931. Građevni je odbor birao Građevinski odbor od tri stručne osobe koje su odobravale građevinske dozvole, parcelacijske elaborate, davale mišljenje o regulacijskoj osnovi i sl. ${ }^{123}$

Grobni odbor skrbio je o radu groblja i grobarskoga osoblja: o grobnim pristojbama, plaćama mrtvozornika, radnom vremenu, preseljenju mrtvaca, održavanju pojedinih grobnica, prijenosu vlasnišstva nad grobnicama i sl. ${ }^{124}$

Kandidacioni odbor razmatrao je molbe za radna mjesta po raspisanim natječajima i predlagao tri kandidata, između kojih je gradsko zastupstvo biralo jednoga. ${ }^{125}$

Karnosni (disciplinski) je odbor djelovao sukladno Zakonu ob ustroju županijah. ${ }^{126}$ Rješavao je disciplinske predmete protiv gradskih službenika koji su povredom ili zanemarivanjem svojih obveza skrivili određenu štetu i donosio prijedloge o disciplinskim kaznama.

\footnotetext{
${ }^{121}$ HR-DAVŽ-5. Zbirka statuta, pravilnika, godišnjaka i pojedinih zakonskih akata, 1.1.2.1.2. Statut slobodnog i kraljevskog grada Varaždina o unutarnjem uređenju gradske uprave, čl. 74.

${ }^{122}$ HR-DAVŽ-5. Zbirka statuta, pravilnika, godišnjaka i pojedinih zakonskih akata, 1.1.2.1.2. Statut slobodnog i kraljevskog grada Varaždina o unutarnjem uređenju gradske uprave, čl. 74.

${ }^{123}$ Građevinski zakon, Zbirka zakona i uredaba 170/1931.

${ }^{124}$ Usp. HR-DAVŽ-649. GPV. 1.3.4. Zapisnici sjednica uboškoga i grobnoga odbora (kut. 6).

${ }^{125}$ HR-DAVŽ-5. Zbirka statuta, pravilnika, godišnjaka i pojedinih zakonskih akata, 1.1.2.1.2. Statut slobodnog i kraljevskog grada Varaždina o unutarnjem uređenju gradske uprave, čl. 41-43.

126 Zakon ob ustroju županijah i uredjenju uprave u županijah i kotarih, Sbornik zakonah i naredabah valjanih za Kraljevinu Hrvatsku i Slavoniju 8/1886.
} 
Odbor za gradska poduzeća bavio se je pitanjima rada i razvoja gradskih poduzeća: Prvoga hrvatskoga varaždinskoga dioničkoga društva za električnu energiju, Gradske ciglane Dubravka i Gradskoga kupališta, a od 1930. i Gradske štedionice. Predmete o Gradskoj ciglani rješavao je i Ciglarski odbor biran sukladno Pravilniku ciglane Dubravka. ${ }^{127}$

Odbor za nužne prolaze djelovao je u skladu sa Zakonom o nužnim prolazima od 6. travnja 1906. godine. ${ }^{128}$ Rješavao je molbe o otvaranju, odnosno ukidanju prolaza, definirao uvjete koje je pritom trebalo zadovoljiti, odlučivao o odštetnim zahtjevima i podnosio molbe za upis u zemljišne knjige o provedbi postupka. Odvojeno su birani odbori za svako naselje u sastavu gradske općine. ${ }^{129}$

Odbor za Ptuj, imenovan 28. travnja 1920. godine zastupao je interese GPV-a na sastancima u Ptuju po pitanju nabave električne energije iz hidroelektrane (munjare) Fala pored Maribora. ${ }^{130}$ Iako je izabran kao stalni odbor, njegova je uloga bila kratkotrajna.

Odbor za potpis obveza gradske općine biran je sukladno čl. 96 ZGO-a iz 1934., u kojem je navedeno da akte »koje obvezuju gradsku općinu predsjednik potpisuje zajedno $s$ dva člana koje bira gradsko vijeće«. ${ }^{131}$

Poljoprivredni je odbor biran sukladno Zakonu o unapređivanju poljoprivrede iz 1929. i u njega su imenovani gradski vijećnici i pojedini zemljoradnici. ${ }^{132}$

Potrošarinski odbor nadgledao je ubiranje gradskih trošarina, rješavao zamolbe za smanjenje trošarina, odnosno oslobađao pojedince plaćanja istih, kontrolirao izvještaje Uprave gradskih daća o mjesečnim prihodima i izvještaje poglavarstva o mjesečnom pregledu gradskih mitnica, dodjeljivao stalna tržišna mjesta i sl. ${ }^{133}$

Pravno-politički odbor izrađivao je prijedloge o oduzimanju mandata zastupnicima, postavljanju i umirovljenju službenika, promjeni teritorijalne nadležnosti gradske općine, statutu, osnutku gradskih poduzeća i ustanova, prora-

\footnotetext{
${ }^{127}$ Usp. HR-DAVŽ-649. GPV. 1.3.3. Zapisnici sjednica odbora za gradska poduzeća (kut. 5).

${ }_{128}$ Zakon o nužnim prolazima, Sbornik zakona i naredaba valjanih za Kraljevine Hrvatsku i Slavoniju 23/1906.

${ }^{129}$ Usp. HR-DAVŽ-649. GPV. 1.1. Zapisnici sjednica Gradskoga zastupstva, zapisnik od 23. studenog 1938., str. 6.

${ }^{130}$ HR-DAVŽ-649. GPV. 1.1. Zapisnici sjednica Gradskoga zastupstva, zapisnik od 28. travnja 1920., točka 5 .

${ }^{131}$ Zakon o gradskim opštinama, Zbirka zakona i uredaba 177/1934, čl. 96.

${ }_{132}$ Zakon o unapređivanju poljoprivrede, Službene novine Kraljevine Srba, Hrvata i Slovenaca 221/1929.

${ }^{133}$ Usp. HR-DAVŽ-649. GPV. 1.3.6. Zapisnici sjednica potrošarinskoga odbora (kut. 7).
} 
čunu, dodjeljivanju zavičajnoga statusa, smještaju vojske, pokretanju ili prekidu sudskih parnica i sklapanju nagodbi, sklapanju odnosno raskidu ugovora i dr. ${ }^{134}$

Školski odbor djelovao je sukladno Zakonu ob uredjenju pučke nastave od 31. listopada 1888. godine. ${ }^{135}$ Predlagao je primanje učitelja u službu, skrbio o materijalnom stanju škola i školskim programima, poticao redovan polazak škole i podnosio gradskomu poglavarstvu na kaznu popise roditelja koji djecu ne šalju u školu, djelovao kao arbitar u sukobima učitelja i roditelja učenika, nadzirao učitelje u izvršavanju obveza i sl. ${ }^{136}$ Školski je odbor uglavnom rješavao i ostala kulturno-prosvjetna pitanja kao Školsko-prosvjetni odbor, a 1929. formiran je i Zanatsko-školski odbor specijaliziran za zanatske škole i osposobljavanje za obrtničke struke. U pojedinim razdobljima djelovao je Prosvjetni odbor kao samostalno tijelo za promicanje općih kulturnih potreba grada. ${ }^{137} \mathrm{U}$ razdoblju 1918.-1925. sličnu je ulogu imao Glazbeno-kazališni odbor, koji je pored kazališnoga života posebno skrbio o gradskoj glazbi.

Upravni odbor rješavao je porezne, disciplinske i sindikalne predmete. Pri provedbi poreznih poslova odbor je bio podređen ministru financija i provodio je njegove odredbe. U disciplinskim je poslovima djelovao u prvostupanjskim poslovima protiv svojih članova, koje su između ostaloga činili gradski načelnik i podnačelnik, a u sindikalnim je poslovima rješavao pritužbe protiv gradskih službenika. ${ }^{138}$

Zdravstveni odbor biran je sukladno Zakonu o uređenju zdravstvene službe u kraljevinah Hrvatskoj i Slavoniji iz 1894. i skrbio je o unaprjeđenju javnoga zdravstva, provođenju mjera protiv zaraznih bolesti, higijenskim uvjetima u gradu i na kupalištu, o bolničkoj opskrbi socijalno ugroženoga stanovništva i sl. ${ }^{139}$

Grad Varaždin, rješenjem ministra trgovine i industrije od 22. prosinca 1936., uvršten je u turistička mjesta te je sukladno Uredbi o unapređenju turizma gradsko zastupstvo 30. ožujka 1937. formiralo stalni Turistički odbor s ciljem napretka turizma u gradu. ${ }^{140}$

\footnotetext{
${ }^{134}$ HR-DAVŽ-5. Zbirka statuta, pravilnika, godišnjaka i pojedinih zakonskih akata, 1.1.2.1.2. Statut slobodnog i kraljevskog grada Varaždina o unutarnjem uređenju gradske uprave, čl. 74.

135 Zakon ob uredjenju pučke nastave i obrazovanja pučkih učiteljah u kraljevinah Hrvatskoj i Slavoniji, Sbornik zakonah i naredabah valjanih za Kraljevine Hrvatsku i Slavoniju 74/1888.

${ }^{136}$ HR-DAVŽ-5. Zbirka statuta, pravilnika, godišnjaka i pojedinih zakonskih akata, 1.1.2.1.2. Statut slobodnog i kraljevskog grada Varaždina o unutarnjem uređenju gradske uprave, čl. 74.

${ }^{137}$ HR-DAVŽ-649. GPV. 1.1. Zapisnici sjednica Gradskoga zastupstva, zapisnik od 30. ožujka 1937., str. 100 , točka 5 .

${ }^{138}$ HR-DAVŽ-5. Zbirka statuta, pravilnika, godišnjaka i pojedinih zakonskih akata, 1.1.2.1.2. Statut slobodnog i kraljevskog grada Varaždina o unutarnjem uređenju gradske uprave, čl. 44-59.

139 Usp. HR-DAVŽ-649. GPV. 1.3.5. Zapisnici sjednica zdravstvenoga odbora (kut. 6).

${ }^{140}$ HR-DAVŽ-649. GPV. 1.1. Zapisnici sjednica Gradskoga zastupstva, zapisnik od 30. ožujka 1937., str. 18 , točka 3.
} 
Nakon što su na konstituirajućoj sjednici gradskoga vijeća 1938. izabrani stalni odbori, sukladno Zakonu o obveznom tjelesnom odgoju osnovan je i imenovan na sjednici 20. travnja 1938. Odbor za tjelesni odgoj ${ }^{141}$ za razvoj sportskih aktivnosti i obrambenih sposobnosti.

Kao posljednji odbor osnovan je odredbom bana br. 8648-VII-1941. na sjednici gradskoga vijeća od 19. veljače 1941. Aprovizacijski odbor, koji se je bavio određivanjem lokalnih potreba za živežnim namirnicama, nabavkom i raspodjelom namirnica, financiranjem aprovizacijskih poslova i sl. ${ }^{142}$

Pored stalnih odbora djelovali su i povremeni tzv. uži odbori, koji su proučavali pojedine aktualne predmete te su svoje uvide i prijedloge iznosili gradskomu vijeću na raspravu i konačnu odluku. Tijekom godina birani su brojni uži odbori, kao što su odbor za proučavanje statuta gradskih namještenika, proučavanje gradskih naredbenika, osnutak gradske štedionice, gradnju osnovne škole, ispitivanje završnih računa gradske bolnice, ispitivanje cijene mesa, redukciju rashoda gradskoga proračuna, žalbe gradskih činovnika, utvrđivanje plaća gradskih službenika, utvrđenje paušalne taracovine industrijskim poduzećima, proučavanje i donošenje prijedloga za naplatu psetarine, izgradnju zgrade Javne burze rada, ispitivanje cjenika gradskih daća, otkup gradskih zgrada, kupnju Ciglane Turčin i dr. ${ }^{143}$

\footnotetext{
${ }^{141}$ HR-DAVŽ-649. GPV. 1.1. Zapisnici sjednica Gradskoga zastupstva, zapisnik od 20. travnja 1938. str. 92, točka 9.

${ }_{142}$ HR-DAVŽ-25. GPV. 2.1. Zapisnici sjednica Gradskoga zastupstva, zapisnik od 19. veljače 1941., str. 56, točka 22.

${ }^{143}$ Usp. HR-DAVŽ-649. GPV. 1.1. Zapisnici sjednica Gradskoga zastupstva, zapisnik od 2. srpnja 1936., str. 34-35; zapisnik od 27. listopada 1936., str. 15; zapisnik od 30. ožujka 1937., str. 51-57, čl. 15; zapisnik od 19. svibnja 1937., str. 4-5, točka 8; zapisnik od 20. travnja 1938., str. 93, točka 11.
} 
Tablica 2. Odbori gradskog zastupstva

\begin{tabular}{|l|}
\hline 1914. \\
\hline Ciglarski \\
\hline Glazbeno-kazališni \\
\hline Gospodarski \\
\hline Građevni \\
\hline Kandidacioni \\
\hline Karnosni \\
\hline $\begin{array}{l}\text { Odbor za nadzor } \\
\text { električne rasvjete }\end{array}$ \\
\hline Odbor za nužne prolaze \\
\hline Potrošarinski \\
\hline $\begin{array}{l}\text { Pravno-politički i } \\
\text { proračunski }\end{array}$ \\
\hline Regulatorni \\
\hline Školski \\
\hline Uboški, bolnički i grobni \\
\hline Upravni \\
\hline
\end{tabular}

\begin{tabular}{|l|}
\hline 1920. \\
\hline Ciglarski \\
\hline Glazbeno-kazališni \\
\hline Gospodarski \\
\hline Građevinski \\
\hline Kandidacioni \\
\hline Karnosni \\
\hline $\begin{array}{l}\text { Odbor za nadzor } \\
\text { električne rasvjete }\end{array}$ \\
\hline Odbor za nužne prolaze \\
\hline $\begin{array}{l}\text { Odbor za Ptuj } \\
\text { (Delegati za Ptuj) }\end{array}$ \\
\hline Potrošarinski \\
\hline $\begin{array}{l}\text { Pravno-politički i } \\
\text { proračunski }\end{array}$ \\
\hline Regulatorni \\
\hline Stočarski \\
\hline Školski \\
\hline Uboški, bolnički i grobni \\
\hline Upravni \\
\hline Zdravstveno kupališni \\
\hline
\end{tabular}

\begin{tabular}{|l|}
\hline 1924. \\
\hline Ciglarski \\
\hline Glazbeno-kazališni \\
\hline Gospodarski \\
\hline Građevni \\
\hline Kandidacioni \\
\hline Karnosni \\
\hline $\begin{array}{l}\text { Nadzorni odbor za } \\
\text { gradsku ekonomiju }\end{array}$ \\
\hline $\begin{array}{l}\text { Odbor za nadzor } \\
\text { električne rasvjete }\end{array}$ \\
\hline Odbor za nužne prolaze \\
\hline Potrošarinski \\
\hline $\begin{array}{l}\text { Pravno-politički i } \\
\text { proračunski }\end{array}$ \\
\hline Regulatorni \\
\hline Stočarski \\
\hline Školski \\
\hline $\begin{array}{l}\text { Uboško-bolnički i } \\
\text { grobni }\end{array}$ \\
\hline Upravni \\
\hline Zdravstveno kupališni \\
\hline
\end{tabular}




\begin{tabular}{|l|}
\hline 1925. \\
\hline Ciglarski \\
\hline Glazbeno-kazališni \\
\hline Gospodarski \\
\hline Građevni \\
\hline Kandidacioni \\
\hline Karnosni \\
\hline $\begin{array}{l}\text { Nadzorni odbor za } \\
\text { gradsku ekonomiju }\end{array}$ \\
\hline $\begin{array}{l}\text { Odbor za nadzor } \\
\text { električne rasvjete }\end{array}$ \\
\hline Odbor za nužne prolaze \\
\hline $\begin{array}{l}\text { Odbor za kontrolu } \\
\text { vatrogasnoga prireza }\end{array}$ \\
\hline Potrošarinski \\
\hline $\begin{array}{l}\text { Pravno-politički i } \\
\text { proračunski }\end{array}$ \\
\hline Regulatorni \\
\hline Stočarski \\
\hline Školski \\
\hline $\begin{array}{l}\text { Uboško-bolnički i } \\
\text { grobni }\end{array}$ \\
\hline Upravni \\
\hline Zdravstveno kupališni \\
\hline
\end{tabular}

\begin{tabular}{|l|}
\hline 1928. \\
\hline Gospodarski \\
\hline Građevni i regulatorni \\
\hline Kandidacioni \\
\hline Karnosni \\
\hline $\begin{array}{l}\text { Odbor za gradska } \\
\text { poduzeća }\end{array}$ \\
\hline Odbor za nužne prolaze \\
\hline Potrošarinski \\
\hline $\begin{array}{l}\text { Pravno-politički, } \\
\text { proračunski i financijski }\end{array}$ \\
\hline Prosvjetni \\
\hline Školski \\
\hline Uboški, bolnički i grobni \\
\hline Zdravstveni \\
\hline
\end{tabular}

\begin{tabular}{|l|}
\hline 1929. \\
\hline Gospodarski \\
\hline Građevni \\
\hline Grobni \\
\hline Kandidacioni \\
\hline Karnosni \\
\hline $\begin{array}{l}\text { Odbor za gradska } \\
\text { poduzeća }\end{array}$ \\
\hline Odbor za nužne prolaze \\
\hline Potrošarinski \\
\hline $\begin{array}{l}\text { Pravno-politički, } \\
\text { proračunski i financijski }\end{array}$ \\
\hline Prosvjetni \\
\hline Školski \\
\hline Uboško-bolnički \\
\hline Zanatsko-školski \\
\hline Zdravstveni \\
\hline
\end{tabular}


Tablica 2. Odbori gradskog zastupstva (nastavak)

\begin{tabular}{|l|}
\hline 1930. \\
\hline Agrarni \\
\hline $\begin{array}{l}\text { Gospodarski } \\
\text { (pododbor: stočarski) }\end{array}$ \\
\hline Građevni i regulatorni \\
\hline Kandidacioni \\
\hline Karnosni \\
\hline $\begin{array}{l}\text { Odbor za gradska } \\
\text { poduzeća }\end{array}$ \\
\hline Odbor za nužne prolaze \\
\hline Potrošarinski \\
\hline $\begin{array}{l}\text { Pravno-politički, } \\
\text { proračunski i financijski }\end{array}$ \\
\hline Prosvjetni \\
\hline Školski \\
\hline Uboški, bolnički i grobni \\
\hline Zanatsko-školski \\
\hline Zdravstveni \\
\hline
\end{tabular}

\begin{tabular}{|l|}
\hline 1936. \\
\hline $\begin{array}{l}\text { Gospodarski } \\
\text { (pododbor: stočarski) }\end{array}$ \\
\hline Građevni i regulatorni \\
\hline Građevinski \\
\hline Karnosni \\
\hline $\begin{array}{l}\text { Odbor za ocjenu } \\
\text { činovnika }\end{array}$ \\
\hline $\begin{array}{l}\text { Odbor za gradska } \\
\text { poduzeća }\end{array}$ \\
\hline $\begin{array}{l}\text { Odbor za nadzor gradske } \\
\text { ciglane }\end{array}$ \\
\hline Odbor za nužne prolaze \\
\hline $\begin{array}{l}\text { Odbor za potpis obaveza } \\
\text { gradske općine }\end{array}$ \\
\hline Poljoprivredni \\
\hline Potrošarinski \\
\hline $\begin{array}{l}\text { Pravno-politički, } \\
\text { proračunski i financijski }\end{array}$ \\
\hline Prosvjetni \\
\hline Školski \\
\hline Uboški, bolnički i grobni \\
\hline Zdravstveni \\
\hline
\end{tabular}

\begin{tabular}{|l|}
\hline ožujak 1938. \\
\hline Gospodarski \\
\hline Građevni \\
\hline Građevinski \\
\hline Karnosni \\
\hline $\begin{array}{l}\text { Odbor za ocjenu } \\
\text { činovnika }\end{array}$ \\
\hline $\begin{array}{l}\text { Odbor za nadzor gradske } \\
\text { ciglane }\end{array}$ \\
\hline Odbor za nužne prolaze \\
\hline $\begin{array}{l}\text { Odbor za potpis obaveza } \\
\text { gradske općine }\end{array}$ \\
\hline Odbor za tjelesni odgoj \\
\hline Poljoprivredni \\
\hline $\begin{array}{l}\text { Pravno-politički, } \\
\text { proračunski i financijski }\end{array}$ \\
\hline Prosvjetni \\
\hline Stočarski \\
\hline Školski \\
\hline Turistički \\
\hline Uboški \\
\hline Zdravstveni \\
\hline
\end{tabular}




\begin{tabular}{|l|}
\hline studeni 1938. \\
\hline Gospodarski \\
\hline Građevni \\
\hline Karnosni \\
\hline $\begin{array}{l}\text { Odbor za ocjenu } \\
\text { činovnika }\end{array}$ \\
\hline $\begin{array}{l}\text { Odbor za nadzor gradske } \\
\text { ciglane }\end{array}$ \\
\hline Odbor za nužne prolaze \\
\hline $\begin{array}{l}\text { Odbor za potpis obaveza } \\
\text { gradske općine }\end{array}$ \\
\hline Poljoprivredni \\
\hline $\begin{array}{l}\text { Pravno-politički, } \\
\text { proračunski i financijski }\end{array}$ \\
\hline Prosvjetni \\
\hline Školski \\
\hline Uboški \\
\hline Zdravstveni \\
\hline
\end{tabular}

\begin{tabular}{|l|}
\hline 1940. \\
\hline Bolničko-uboški \\
\hline Disciplinski \\
\hline Gospodarski \\
\hline Građevni \\
\hline $\begin{array}{l}\text { Odbor za ocjenu } \\
\text { činovnika }\end{array}$ \\
\hline $\begin{array}{l}\text { Odbor za nadzor gradske } \\
\text { ciglane }\end{array}$ \\
\hline Odbor za nužne prolaze \\
\hline $\begin{array}{l}\text { Odbor za potpis obaveza } \\
\text { gradske općine }\end{array}$ \\
\hline Poljoprivredni \\
\hline Potrošarinski \\
\hline $\begin{array}{l}\text { Pravno-politički, } \\
\text { proračunski i financijski }\end{array}$ \\
\hline Prosvjetni \\
\hline Školski \\
\hline Zdravstveni \\
\hline
\end{tabular}




\subsection{Gradsko poglavarstvo}

Gradsko poglavarstvo (ponekad označavano srednjovjekovnim nazivom magistrat ili u duhu jugoslavenske terminologije načelstvo) bilo je izvršno tijelo sastavljeno od perovodnoga, stručnoga i pomoćnoga osoblja na čijem je čelu bio načelnik. ${ }^{144} \mathrm{U}$ perovodno osoblje pripadala su dva gradska vijećnika, gradski kapetan i tajnik sa završenim pravnim fakultetom i položenim državnim stručnim ispitom, a stručno su osoblje činili zdravstveni, veterinarski, građevinski, šumarski i drugi stručni djelatnici. U slučaju spriječenosti načelnika je, kao čelnika poglavarstva, mijenjao jedan od dvojice gradskih vijećnika. Sve je službenike, uključujući perovodne, stručne i pomoćne, putem natječaja biralo zastupstvo na prijedlog kandidacijskoga odbora, izuzev gradskoga kapetana, kojega je na čelo redarstvene referade imenovala viša državna vlast. ${ }^{145}$ Gradski je kapetan polagao prisegu banu, odnosno oblasnomu velikom županu, a šefovi ostalih odsjeka gradskomu načelniku. Službenici su za svoj rad dobivali plaću i imali pravo na opskrbu, a sva njihova prava i obveze bile su uređene posebnim statutom koji je donosilo gradsko zastupstvo. ${ }^{146}$ Disciplinske postupke protiv službenika pokretao je načelnik na zahtjev gradskoga zastupstva ili nadzornih tijela, a provodio gradski disciplinski sud prvoga stupnja, odnosno viši disciplinski sud pri Banskoj upravi u drugom stupnju. ${ }^{147}$

Poglavarstvo je obavljalo sve prenesene upravne poslove koji su mu zakonom stavljeni u nadležnost ${ }^{148}$ te je provodilo zaključke gradskoga zastupstva i upravljalo unutarnjim poslovima gradske općine. ${ }^{149}$ Gradski je načelnik dodjeljivao zadatke gradskim službenicima te je za poslovanje poglavarstva u prenesenom djelokrugu odgovarao višoj oblasti, a u unutarnjem gradskom zastupstvu. ${ }^{150}$ Sukladno ZGO-u iz 1885. gradsko je zastupstvo nadgledalo rad poglavarstva, a ZGO-om iz 1934. posao kontrole uglavnom je prenesen na predsjednika, iako je zastupstvo i nadalje bilo nadležno poglavarstvu u obavljanju samoupravnih poslova. Počevši od studenoga 1929. godine poglavarstvo je bilo obvezno Banskoj upravi dostavljati dvomjesečne izvještaje o stanju javne uprave iz područja

\footnotetext{
${ }^{144}$ HR-DAVŽ-5. Zbirka statuta, pravilnika, godišnjaka i pojedinih zakonskih akata, 1.1.2.1.2. Statut slobodnog i kraljevskog grada Varaždina o unutarnjem uređenju gradske uprave, čl. 79.

${ }^{145}$ HR-DAVŽ-5. Zbirka statuta, pravilnika, godišnjaka i pojedinih zakonskih akata, 1.1.2.1.2. Statut slobodnog i kraljevskog grada Varaždina o unutarnjem uređenju gradske uprave, čl. 89.

${ }^{146}$ Statuti za službenike grada Varaždina redovno su ažurirani: u Zbirki statuta, pravilnika, godišnjaka i pojedinih zakonskih akata (HR-DAVŽ-5) tijekom razdoblja 1918.-1941. evidentirano je sedamnaest statuta, dopuna, propisnika o statutu i pravilnika za napredovanje službenika.

${ }_{147}$ Zakon o gradskim opštinama, Zbirka zakona i uredaba 177/1934, čl. 107-108.

148 Zakon o gradskim opštinama, Zbirka zakona i uredaba 177/1934, čl. 89. Usp. Statut slobodnog i kraljevskog grada Varaždina o unutarnjem uređenju gradske uprave, čl. 93.

${ }_{149}$ Zakon o gradskim opštinama, Zbirka zakona i uredaba 177/1934, čl. 88.

${ }^{150}$ Zakon o gradskim opštinama, Zbirka zakona i uredaba 177/1934, čl. 96.
} 
zdravstva i socijalne skrbi, obrta, industrije i trgovine, prosvjete i građevinske djelatnosti. ${ }^{151}$

Razdioba poslova unutar poglavarstva obavljana je isprva po referadama, zatim odsjecima i pojedinim zavodima i uredima. Odsjeci u pravilu nisu vodili vlastite spisovodstvene evidencije i većina je spisa evidentirana u jedinstvenim urudžbenim zapisnicima te odlagana u redovne spise. Nedostatak definiranih registraturnih planova otežava identifikaciju ustrojbenih jedinica, odnosno praćenje njihove reorganizacije tijekom vremena. Za relevantni prikaz korišteni su raspoloživi izvori: statut, pojedine gradske okružnice ili dostavnice koje su potpisivali svi voditelji odsjeka.

Statutom iz 1896. propisana je razdioba poslova gradskoga poglavarstva na šest referada: I. gospodarsku, II. pravno-političku, III. redarstvenu, IV. građevnu, V. zdravstvenu, VI. sirotinjsko-skrbničku.

I gospodarska i pravno-politička referada upravljale su gradskom imovinom, s time da je djelokrug prve uključivao upravljanje nekretninama, gradskim poduzećima i javnim površinama, a u djelokrug druge pripadali su proračun, gradski prihodi i plaće osoblja. Osim navedenoga, referada II. obuhvaćala je i mnoge druge poslove, kao što su vođenje centralne pismohrane, briga o gradskom kazalištu i gradskoj glazbi, groblju, uboškim zavodima i dobrotvornim društvima, bogoštovlju i školstvu, vojnim, katastarskim, izbornim poslovima, provedba zakona o zadrugama, ubiranje državnoga poreza i $\mathrm{dr}^{152}$

Redarstvena je referada pokrivala širok raspon poslova, od održavanja javne sigurnosti do poslova pojedinih upravnih grana. ${ }^{153} \mathrm{U}$ djelokrug javne sigurnosti pripadali su stražarski ophodi i inspekcije, nadzor društveno-političke klime i javnoga morala (prostitucija, konkubinat, zaštita životinja, obilježavanje blagdana), izdavanje potvrda o vladanju, oružani listovi, odobrenja za javna okupljanja i dr. Od upravnih je poslova Redarstvena referada obavljala poslove obrta i trgovine te tržišne inspekcije na sajmovima i u gradskoj klaonici. Osim navedenoga, vodila je i evidencije stanovništva (državljanstva, migracija, promjene imena i vjere, primanje u zavičajni savez, popise stanovništva), izdavala je putovnice i propusnice, služinske i radničke knjige, provodila potrage za osobama nepoznata boravišta. ${ }^{154}$ Rješenjem velikoga župana Redarstvena je referada 1. prosinca 1924.

${ }^{151}$ HR-DAVŽ-649. GPV, 3.1.3. Redovni spisi, okružnica Kr. banske uprave od 26. prosinca 1929., br. $17680 / 1929$.

${ }^{152}$ HR-DAVŽ-5. Zbirka statuta, pravilnika, godišnjaka i pojedinih zakonskih akata, 1.1.2.1.2. Statut slobodnog i kraljevskog grada Varaždina o unutarnjem uređenju gradske uprave, dodatak: Razredba poslova kod gradskog poglavarstva u Varaždinu, str. 44-45.

${ }^{153}$ Ivo Krbek, Upravno pravo: I. knjiga: Uvodna i osnovna pitanja (Zagreb: Jugoslovenska štampa, 1929), str. 80-81.

${ }^{154}$ HR-DAVŽ-5. Zbirka statuta, pravilnika, godišnjaka i pojedinih zakonskih akata, 1.1.2.1.2. Statut slobodnog i kraljevskog grada Varaždina o unutarnjem uređenju gradske uprave, dodatak: Razredba poslova kod gradskog poglavarstva u Varaždinu, str. 48-52. 
izdvojena iz poglavarstva te je premještena pod državnu upravu. ${ }^{155}$ Tim činom redarstvo je postalo samostalna državna oblast podređena oblasnomu velikomu županu pod nazivom Kr. redarstveno povjereništvo u Varaždinu. Kako država nije podmirivala dio svojih obveza, veliki je župan otpisom br. 11089. od 12. veljače 1926. ukinuo Kr. redarstveno povjereništvo i ponovno redarstvo stavio pod upravu gradskoga poglavarstva 23. veljače 1926. godine. ${ }^{156}$

Građevna referada skrbila je o građevinsko-komunalnoj djelatnosti i urbanističkom razvoju grada, ${ }^{157}$ a zdravstvena o radu gradske bolnice i ljekarni te provođenju zdravstvenih i veterinarskih mjera. ${ }^{158} \mathrm{U}$ djelokrug VI. referade pripadali su poslovi Sirotinjskoga povjerenstva i Mjesnoga suda za područje grada Varaždina. ${ }^{159}$ Navedeni sud, ustrojen sukladno zakonu iz $1876 .,{ }^{160}$ bio je nadležan u građansko-pravnim sporovima kojima su uređivana osobna i imovinska prava manjega novčanoga cenzusa. Zakonom od 6. veljače 1929. proširena je nadležnost mjesnih sudova u gradovima s predmeta čija je tužena vrijednost iznosila do 150 dinara na one čija je vrijednost dosezala 1.000 dinara. Time je znatno povećan i broj njegovih predmeta. ${ }^{161}$ Sirotinjsko povjerenstvo kao posebna ustanova vodila je zasebnu pismohranu i u pravilu nije ulazila u organizacijsku shemu poglavarstva, iako su njegova predsjednika (ujedno suca Kotarskoga suda) i članove (tzv. prisjednike) birali gradski vijećnici. Nadležnost povjerenstva bila je određena Naputkom o obavljanju sirotinjskih i skrbničkih poslova iz 1851., sukladno kojemu su sirotinjska povjerenstva osnovana za obavljanje sirotinjskih i skrbničkih poslova, određivanje tutora ili skrbnika, brigu o imovini malodobnika odnosno skrbljenika, vođenje brige o štićenicima, utvrđivanje očinstva, uređivanje alimentacije za vanbračnu djecu i rješavanje drugih predmeta u izvanparničnim postupcima. ${ }^{162}$

\footnotetext{
155 HR-DAVŽ-649. GPV, 2.4. Povjerljivi spisi, br. 33/1924.

${ }^{156}$ HR-DAVZ-649. GPV, 1.1. Zapisnici sjednica Gradskoga zastupstva, zapisnik od 22. travnja 1926., čl. 42 .

${ }^{157}$ HR-DAVŽ-5. Zbirka statuta, pravilnika, godišnjaka i pojedinih zakonskih akata, 1.1.2.1.2. Statut slobodnog i kraljevskog grada Varaždina o unutarnjem uređenju gradske uprave, dodatak: Razredba poslova kod gradskog poglavarstva u Varaždinu, str. 52-53.

${ }^{158}$ HR-DAVŽ-5. Zbirka statuta, pravilnika, godišnjaka i pojedinih zakonskih akata, 1.1.2.1.2. Statut slobodnog i kraljevskog grada Varaždina o unutarnjem uređenju gradske uprave, dodatak: Razredba poslova kod gradskog poglavarstva u Varaždinu, str. 54.

${ }^{159}$ HR-DAVŽ-5. Zbirka statuta, pravilnika, godišnjaka i pojedinih zakonskih akata, 1.1.2.1.2. Statut slobodnog i kraljevskog grada Varaždina o unutarnjem uređenju gradske uprave, dodatak: Razredba poslova kod gradskog poglavarstva u Varaždinu, str. 55.

160 Zakon od mjestnih sudovih i postupku pred njimi, Sbornik zakonah i naredabah valjanih za Kraljevine Hrvatsku i Slavoniju 87/1876.

${ }^{161}$ HR-DAVŽ-649. GPV, 1.1. Zapisnici sjednica Gradskoga zastupstva, zapisnik od 12. travnja 1929., točka 38 Pravno-političkoga odbora.

${ }^{162}$ Dubravka Čengić, “Sirotinjsko povjerenstvo grada Zagreba 1856-1946," Arhivski vjesnik 41 (1998): str. 111-119.
} 
U sklopu GPV-a djelovala je još jedna posebna ustanova s vlastitom pismohranom koja nije ulazila u ustrojbenu podjelu poglavarstva. Riječ je o Stanarinskom uredu osnovanom 1918. na temelju Naredbe Narodnog vijeća SHS o prisilnom iznajmljivanju prostorija i drugim odredbama za ublažavanje oskudice za stanovima. ${ }^{163}$ Ured je obavljao sve propisane poslove (rješavao molbe za stanove, iznajmljivao prazne stambene ili uredske prostore potrebitim osobama, vodio očevidnike o prostorima za iznajmljivanje i svim najamnim odnosima i dr.) izuzev kazneno-redarstvenoga postupka. Sastojao se od predsjednika i zamjenika, koje je biralo gradsko zastupstvo između perovodnih činovnika i određenoga broja prisjednika biranih između najmodavaca i najmoprimaca. ${ }^{164}$

Pored ustrojbenih jedinica razrađenih statutom djelovale su i tri stalne organizacijske jedinice zadužene za gradske financije: gradska blagajna i porezni ured, gradsko računovodstvo i uprava gradskih daća. Praćenje njihove djelatnosti tijekom cijeloga međuratnoga razdoblja posebno olakšava njihova samostalna, u velikoj mjeri sačuvana pismohrana.

Organizacijski sustav propisan statutom nije dugo ostao na snazi: pojedini su odsjeci ukidani, spajani, postajali podjedinice drugih odsjeka ili su pak referade izrastale u samostalne odsjeke. Ustroj nije bio jasno strukturiran i za iste odsjeke korišteni su različiti nazivi, što je vidljivo iz okružnice kojom je 31. svibnja 1928. povjerenik Dragojlović propisao službene nazive i definirao trinaest odsjeka i ureda: 1. Gradski građevni ured, 2. Gradski fizikat, 3. Redarstveni odsjek, 4. Šumarsko-gospodarstveni ured, 5. Gradsko računovodstvo, 6. Gradska blagajna i porezni ured, 7. Veterinarski odsjek (gradska klaonica, veterinarski ured, veterinarska pregledna postaja i ured za izdavanje stočnih pasoša), 8. Ured za označavanje bačava, 9. Uprava gradskog groblja, 10. Gradsko vrtlarstvo, 11. Ravnateljstvo državne ženske građanske, osnovne i stručne škole, 12. Ravnateljstvo državne dječačke osnovne škole, 13. Uprava gradskih daća. ${ }^{165}$ Iz nove je sheme razvidno da je Zdravstvena referada podijeljena na Zdravstveni (gradski fizik) i Veterinarski odsjek, da je iz Gospodarske referade izdvojeno u samostalni odsjek Gradsko vrtlarstvo, a iz Pravno-političke Uprava gradskog groblja i ravnateljstva škola. Ured za označavanje bačava, odnosno Baždarski ured djelovao je pri GPV-u od 1875. do 31. prosinca 1931., kada su sukladno Zakonu o uređenju službe kontrolisanja merila i dragocenih metala od 2. prosinca $1930 .^{166}$

\footnotetext{
${ }^{163}$ HR-HDA-79. UOZV, Naredbe Narodnoga vijeća SHS o prisilnom iznajmljivanju prostorija i drugim odredbama za ublažavanje oskudice za stanovima, sv. IV-1, br. 67766/1918.

${ }^{164}$ HR-HDA-79. UOZV, Naredbe Narodnoga vijeća SHS o prisilnom iznajmljivanju prostorija i drugim odredbama za ublažavanje oskudice za stanovima, sv. IV-1, br. 67766/1918, čl. 15-17.

${ }^{165}$ HR-DAVŽ-649. GPV, 3.1.3. Redovni spisi, br. 4800/1928.

166 Zakon o uređenju službe kontrolisanja merila i dragocenih metala pri opštim upravnim vlastima, Zbirka zakona i uredaba 80/1931.
} 
njegovi poslovi preneseni na Ured za kontrolu mjera i dragocjenih metala pri kotarskoj oblasti. ${ }^{167}$

Iz iskaza gradskih službenika i činovnika proizlazi da je početkom 1931. ustroj donekle izmijenjen, iako se je još uvijek sastojao od trinaest odsjeka: I. Pravno-politički odsjek, II. Građevni odsjek, III. Šumarsko-gospodarski odsjek, IV. Zdravstveni odsjek, V. Veterinarski odsjek, VI. Gradsko sirotinjsko povjerenstvo i mjesni sud, VII. Gradsko računovodstvo, VIII. Gradska blagajna i porezni ured, IX. Uprava gradskih daća, X. Ured za označavanje bačava, XI. Arhiv administrativni činovnici; XII. Redarstveni odsjek. ${ }^{168} \mathrm{Iz}$ istoga iskaza vidljivo je da su unutar pravno-političkoga odsjeka dva gradska vijećnika obavljali, pored pravno-političkih i personalne poslove, nadzor nad vojnom referadom i dr. U tom je razdoblju Građevni odsjek u svojem sastavu imao Tehnički odsjek i Cestovnu referadu. Zdravstveni je odsjek obavljao zdravstveno-socijalne, dezinfekcijske poslove, provodio tržni nadzor i upravljao gradskim grobljem, koje je u prethodnom razdoblju bilo samostalna jedinica. U Arhivu su vođeni urudžbeni zapisnici i kazala redovnih spisa, urudžbeni zapisnik gradskoga načelnika, vojne evidencije, imenici zavičajnika i dr. Iz citiranoga je dokumenta razvidno i da je redarstveni odsjek velik dio svojega osoblja prenio na Predstojništvo gradske policije. Naime, od 1929. godine na temelju Uredbe o ustrojstvu predstojništva gradske policije u gradovima izvan sjedišta banovine od 4. studenoga $1929 .{ }^{169}$ osnovano je u Varaždinu Predstojništvo gradske policije. Administrativni troškovi i plaće redarstvenih djelatnika i nadalje su pokrivani iz gradskoga proračuna ${ }^{170}$ te je Predstojništvo redovno provodilo komunikaciju s poglavarstvom po pitanju nabave materijala, osiguranja radnih prostora i zapošljavanja djelatnika. ${ }^{171}$

Kako bi se što efikasnije rješavali predmeti o socijalno ugroženim i bolesnim osobama, djeci bez roditelja i nezaposlenima, pri gradskom je poglavarstvu 1. rujna 1936. osnovan socijalni odsjek u koji je ušao i Mjesni odbor za nezaposlene. ${ }^{172}$ Predsjednik gradske općine o tom je podnio izvještaj na sjednici vijeća 27. listopada 1936., i to je bila prva rasprava posvećena ustroju. ${ }^{173}$ Do tada grad-

\footnotetext{
${ }^{167}$ HR-DAVŽ-649. GPV, 1.1. Zapisnici sjednica Gradskoga zastupstva, zapisnik od 5. listopada 1931., točka 20 Pravno-političkoga odbora.

${ }^{168}$ HR-DAVŽ-649. GPV, 2.4. Povjerljivi spisi, iskaz gradskih činovnika i službenika razvrstanih po odjeljenjima, br. 4/1931.

${ }^{169}$ Hrvoje Čapo, Kraljevina čuvara: Represivni aparat monarhističke Jugoslavije na području hrvatskih zemalja (1918.-1941.) (Zagreb: Hrvatski institut za povijest, 2015), str. 250.

170 Čapo, Kraljevina čuvara, str. 251.

${ }^{171} \mathrm{O}$ suradnji Predstojništva gradske policije i gradske uprave svjedoči uglavnom povjerljiva prepiska (HR-DAVŽ-649. GPV, kut. 9-13) i zapisnici sjednica gradskoga zastupstva.

${ }^{172}$ HR-DAVŽ-649. GPV, 1.1. Zapisnici sjednica Gradskoga zastupstva, zapisnik od 27. listopada 1936., str. 42-44, točka 2.

${ }^{173}$ HR-DAVŽ-649. GPV, 1.1. Zapisnici sjednica Gradskoga zastupstva, zapisnik od 27. listopada 1936., str. 42-44, točka 2.
} 
sko vijeće nije odlučivalo o organizaciji poglavarstva. O pokušajima unaprjeđenja ustroja u 1936. godini svjedoči i činjenica da je tijekom kolovoza gradski izaslanik posjetio Maribor, Ljubljanu i Zagreb kako bi proučio administraciju tih gradova te primijenio njihov ustroj u Varaždinu. ${ }^{174}$ Rezultati su bili vidljivi već naredne godine, kada je uputstvom uvedeno sustavno označavanje spisa rimskim brojevima. ${ }^{175}$ Do tada su spisi sporadično obilježavani brojčanim oznakama, a u spisovodstvenim je evidencijama samo povremeno naznačena pripadnost ustrojbenoj jedinici. Sukladno spomenutomu uputstvu razrađeno je dvanaest odsjeka s pripadajućim brojčanim oznakama: I. Šumarsko-gospodarski odsjek, II. Pravno-politički odsjek, III. Veterinarski odsjek, IV. Građevni odsjek, V. Gradski fizikat, VI. Socijalni odsjek, VII. Vojni odsjek, VIII. Ravnateljstvo pomoćnih ureda, IX. Uprava gradskih daća, X. Tržno nadzorništvo, XI. Gradska vrtlarija, XII. Uprava gradskog groblja.

Nova razdioba iz 1937. precizno je strukturirana i jasno oslikava organizaciju poslova, te je primjenjivana i u narednim godinama. Iste je godine adaptiran i radni prostor poglavarstva kako bi svaki odsjek dobio zaseban i adekvatan prostor za rad. ${ }^{176}$

Sukladno Zakonu o obveznom tjelesnom odgoju od 26. ožujka 1935., na sjednici vijeća 20. travnja 1938. poglavarstvo je predložilo osnivanje Odsjeka obaveznog tjelesnog odgoja za skrb o tjelesnom zdravlju, promicanje tjelesne aktivnosti ${ }^{177} \mathrm{i}$, sukladno Uredbi o osnivanju i radu prazničnih tečajeva ${ }^{178}$ od 23. veljače 1937., planiranje sportskih tečajeva. Kako je rat bio na pomolu, u nadležnost odsjeka i program tjelesnoga odgoja uskoro je pridodan i program zaštite od napada iz zraka. ${ }^{179}$ Novi je odsjek uklopljen u postojeći ustrojbeni model kao XIII. jedinica.

\section{Zaključak}

U razdoblju između dva svjetska rata Gradsko poglavarstvo Varaždin djelovalo je na temelju dvaju zakona: Zakona ob ustroju gradskih obćinah u kraljevinah Hrvatskoj i Slavoniji iz 1895. i Zakona o gradskim općinama iz 1934.

\footnotetext{
${ }^{174}$ HR-DAVŽ-649. GPV, 1.1. Zapisnici sjednica Gradskoga zastupstva, zapisnik od 27. listopada 1936., str. 63, točka 39.

${ }^{175}$ HR-DAVŽ-649. GPV, 3.1.3. Redovni spisi, br. 4791/1937.

176 HR-DAVŽ-649. GPV. 1.1. Zapisnici sjednica Gradskoga zastupstva, zapisnik od 30. ožujka 1937., votum separatum.

177 HR-DAVŽ-649. GPV, 1.1. Zapisnici sjednica Gradskoga zastupstva, zapisnik od 20. travnja 1938., str. 92 .

${ }_{178}$ Uredba o izmeni Uredbe o osnivanju i radu prazničkih tečajeva i izvršenju ostalih odredaba zakona o obaveznom telesnom vaspitanju, Zbirka zakona i uredaba 126/1937.

${ }^{179}$ HR-DAVŽ-649. GPV, 2.4. Povjerljivi spisi, br. 110/1938.
} 
godine. Njima je ozakonjena gradska samouprava i djelomična autonomija u predmetima koji se tiču lokalne zajednice i njezinih stanovnika. U praksi je gradska samouprava često bila sužavana centralističko-apsolutističkim pritiscima, osobito od diktature 1929. godine. I pojedine stavke iz dva osnovna zakona ograničavale su gradsku samoupravu: sukladno ZGO-u iz 1895. nadležno je tijelo imalo pravo poništiti zaključke gradskoga zastupstva i iz važnih razloga raspustiti zastupstvo i zamijeniti ga vladinim povjerenikom, a sukladno ZGO-u iz 1934., pored navedenoga, ban je imenovao jednu trećinu vijećnika. Posljednja odredba nije primijenjena u praksi jer su od 1929. cjelokupna gradska vijeća, a ne samo trećina, bila imenovana.

Tijela gradske uprave činili su gradsko zastupstvo odnosno vijeće, načelnik odnosno predsjednik i poglavarstvo tj. načelstvo. Zastupstvo je bilo lokalno predstavničko tijelo, sastavljeno od trideset zastupnika, koje je donosilo zaključke iz samoupravnoga djelokruga. Načelnik je predsjedao zastupstvom i upravljao radom poglavarstva. Poglavarstvo je bilo izvršno-upravno tijelo koje je provodilo zaključke zastupstva i obavljalo upravne poslove prvoga stupnja koje mu je država stavila u nadležnost. Osim navedenih tijela, važnu ulogu u GPV-u imali su stalni odbori, koji su kao upravno-savjetodavno tijela usmjeravali rad gradskoga zastupstva.

Tijekom dvadesetih godina gradsko je zastupstvo birano u četiri navrata. Iako je mandat sukladno zakonu trajao šest godina, sva su se četiri zastupstva raspala prije vremena zbog političko-stranačkih nesuglasica, nedostatka čvrste koalicije ili osobnih animoziteta. Najdulje, točnije četiri godine i sedam mjeseci, djelovalo je zastupstvo izabrano 27. ožujka 1920. na prvim izborima u Kraljevstvu SHS. Drugi mandat zastupstva izabranoga 25. listopada 1925. ugašen je nakon godine i jednoga mjeseca, treći izabran 15. svibnja 1927. nije se uspio ni konstituirati, a četvrti izabran 15. srpnja 1928. potrajao je svega sedam i pol mjeseci, kada su uvođenjem Šestosiječanjske diktature i sukladno Zakonu o izmeni Zakona o opštinama i oblasnim samoupravama prvih mjeseci 1929. raspuštena sva gradska zastupstva. Od 1929. pa do 1941. sva su daljnja zastupstva i načelnici imenovani odlukom bana. Za vrijeme Savske banovine postavljena su četiri gradska vijeća, iako su pojedina tijekom mandata izmijenila sastav iz temelja. Uspostavom Banovine Hrvatske razriješeno je dotadašnje vijeće i postavljen vladin povjerenik, koji je obavljao poslove iz kompetencije vijeća, a tek je u svibnju 1940. na temelju čl. 147. ZGO-a iz 1934. imenovano novo vijeće, koje je ostalo na dužnosti narednih jedanaest mjeseci do proglašenja NDH.

Kako je vlast u gradu Varaždinu tijekom dvadesetih bila prilično nepostojana, tako su i načelnici često odstupali s dužnosti. Na njihovo mjesto vlast je postavljala vladine povjerenike, što je tijekom tridesetih, uz imenovanje načelnika, postalo legitimna praksa režimske politike. Tijekom međuratnoga razdoblja u Varaždinu su djelovala četiri izabrana načelnika (od kojih je jedan izabran 1914.), osam imenovanih (od kojih je jedan obnašao mandat u dva navrata) i šest vladinih povjerenika. Najdugovječniji izabrani načelnik bio je Vjenceslav Podga- 
jski, čiji je mandat trajao četiri i pol godine (ako se ne računa Pero Magdić izabran 1914.). Najdugovječniji imenovani načelnik bio je Stjepan Novaković, također s četiri i pol godišnjim mandatom. Nedvojbeno najdugovječniji vladin povjerenik Dušan Dragojlović dužnost je obavljao čak devetnaest mjeseci. Iako je dužnost vladina povjerenika predviđena kao privremeno rješenje do izbora načelnika, ona je tijekom dvadesetih godina korištena pet puta kako bi se na vlasti što dulje zadržale politički podobne osobe. Od početka diktature 1929. do 1941. samo je jednom postavljen vladin povjerenik u trajanju od sedam mjeseci koji je potom imenovan načelnikom. Od osam imenovanih načelnika četvorica su zapravo imenovana vršiteljem dužnosti do postavljanja novoga načelnika. U praksi nije bilo razlike između vršitelja dužnosti, imenovanoga načelnika i vladina povjerenika: svi su postavljeni od strane režima te su trebali zastupati aktualnu ideologiju jugoslavenstva i utišavati političke i stranačke oponente. Jedina razlika između imenovanih načelnika i povjerenika bila je u širini djelokruga: imenovani načelnik imao je ovlasti istovjetne izabranomu načelniku, a povjerenik sužene i svedene na obavljanje tekućih poslova.

Za efikasnije rješavanje predmeta i brže donošenje zaključaka zastupstvo je imalo stalne i povremene (uže) odbore. Stalni su odbori osnovani sukladno statutu i potrebama gradske općine (Pravno-politički, Potrošarinski, Gospodarski, Uboški, Odbor za gradska poduzeća i dr.) ili na temelju partikularne zakonske regulative (Školski, Poljoprivredni, Odbor za nužne prolaze, Zdravstveni, Karnosni i dr.). Njihov je broj varirao tijekom godina između dvanaest i osamnaest. Najviše odbora (osamnaest) izabrano je 1925., najmanje (dvanaest) 1928. godine. Najveći broj predmeta po sjednici, povremeno i oko sedamdesetak, rješavali su pravno-politički, uboški i gospodarski odbor.

Obavljanje svih upravnih i samoupravnih poslova pripadalo je u domenu poglavarstva. Za efikasno obavljanje poslova od velike su važnosti pouzdana organizacija spisovodstvenoga sustava i logičan ustroj administrativnih službi. Da je Gradsko poglavarstvo Varaždin upravo tomu davalo premalo pažnje svjedoči izostanak ikakve rasprave o ustrojbenom i registraturnom sustavu u zapisnicima sjednica. Godine 1928. zamijećen je pokušaj uvođenja reda u ustroj poglavarstva okružnicom kojom su propisani točni nazivi ustrojbenih jedinica. Najveći pomak u pravcu bolje organizacije učinjen je tek 1937., kada je ustaljen broj odsjeka te je započelo sustavno označavanje spisa brojčanim oznakama ustrojbenih jedinica. Poslovanje je od tada provođeno u dvanaest, odnosno trinaest odsjeka (1938. uveden je jedan odsjek) i takav je ustroj zadržan do 1941. godine. Za unaprjeđenje ustroja svakako su zaslužni stručni posjeti pismohranama drugih gradova, osobito Zagreba. No, za razliku od velikih pismohrana, kod kojih je svaka ustrojbena jedinica vodila urudžbene zapisnike i zasebno odlagala spise, u GPV-u su vođene opće spisovodstvene evidencije i provođeno odlaganje svih spisa (izuzev financijskih) u redovne spise, što u konačnici otežava pronalaženje potrebnoga gradiva i ne oslikava ustroj organizacijskih jedinica. 
Ovaj rad trebao bi, kroz prikaz i analizu ustroja, nadležnosti i djelovanja Gradskoga poglavarstva Varaždin, olakšati istraživačima snalaženje u gradivu jednoga od izuzetno vrijednih, često korištenih i istraživanih fondova Državnoga arhiva u Varaždinu. Također, može poslužiti kao smjernica u razumijevanju upravne povijesti drugih gradskih poglavarstava kontinentalne Hrvatske, osobito gradova prvoga reda, ali i ostalih manjih gradskih općina čije je poslovanje definirano istom zakonskom regulativom i općom društveno-političkom klimom međuratnoga razdoblja. I na kraju, ali ne manje važno, ovaj prikaz jedan je u nizu radova koji, kroz analizu mandata i rada gradskoga zastupstva uvjetovanoga lokalnom stranačkom i državnom režimskom politikom, produbljuje spoznaje i širi sliku o povijesti Hrvatske unutar Kraljevstva, odnosno Kraljevine SHS i Kraljevine Jugoslavije.

\section{POPIS IZVORA}

\section{Arhivsko gradivo}

\section{Državni arhiv u Varaždinu} skih akata.

HR-DAVŽ-5. Zbirka statuta, pravilnika, godišnjaka i pojedinih zakon-

HR-DAVŽ-25. Gradsko poglavarstvo Varaždin (GPV), 1941.-1945.

HR-DAVŽ-649. Gradsko poglavarstvo Varaždin (GPV), 1918.-1941.

\section{Hrvatski državni arhiv}

HR-HDA-78. Zemaljska vlada, Predsjedništvo (PRZV).

HR-HDA-79. Zemaljska vlada, Odjel za unutarnje poslove (UOZV).

HR-HDA-102. Varaždinska županija (VŽ).

HR-HDA-137. Pokrajinska uprava za Hrvatsku i Slavoniju (PU).

HR-HDA-141. Zagrebačka oblast (ZO).

HR-HDA-144. Savska banovina. Upravno odjeljenje (SBUO).

HR-HDA-157. Banovina Hrvatska. Odjel za unutarnje poslove (BHOUP).

\section{Službena glasila i tisak}

Hrvatsko jedinstvo (Varaždin), 1939.

Narodno jedinstvo (Varaždin), 1922, 1925, 1927-1929. 
Naše pravice (Varaždin), 1924.

Sbornik zakonah i naredabah valjanih za Kraljevine Hrvatsku i Slavoniju (Zagreb), 1876, 1885, 1886, 1888.

Slobodni gradanin (Varaždin), 1919, 1920.

Službene novine Kraljevine Srba, Hrvata i Slovenaca (Beograd), 1922, 1929.

Varaždinske novosti (Varaždin), 1930, 1931, 1938.

Volja naroda (Varaždin), 1919.

Zbirka zakona i uredaba (Zagreb), 1931, 1934, 1937.

Zbornik zakona i naredaba valjanih za Hrvatsku i Slavoniju (Zagreb), 1906, 1914, 1918, 1919.

Zbornik zakona, uredbi i naredbi (Zagreb), 1929.

\section{Literatura}

Čapo, Hrvoje. Kraljevina čuvara: Represiuni aparat monarhističke Jugoslavije na području hrvatskih zemalja (1918.-1941.). Zagreb: Hrvatski institut za povijest, 2015.

Čengić, Dubravka. “Sirotinjsko povjerenstvo grada Zagreba 1856-1946." Arhivski vjesnik 41 (1998): str. 111-119.

Grgić, Stipica. “Općinske uprave u vrijeme šestosiječanjske diktature.” Časopis za suvremenu povijest 45, br. 1 (2013): str. 89-117.

Grgić, Stipica. Izmectu režimske ideologije i potreba gradana: Savska banovina 1929-1939. Zagreb: Fakultet hrvatskih studija Sveučilišta, 2020.

Huzjan, Vladimir, Ivan Obadić. "Historiografija varaždinskog kraja u 20. stoljeću." Historia Varasdiensis 1 (2012): str. 67-73.

Janjatović, Bosiljka. Politički teror u Hrvatskoj 1918.-1935. Zagreb: Hrvatski institut za povijest, 2002.

Kolar-Dimitrijević, Mira. "Reakcije Varaždinaca na ukinuće Varaždinske županije 1922. godine i posljedice tih promjena." U 800 godina slobodnog i kraljevskog grada Varaždina 1209.-2009., ur. Miroslav Šicel i Slobodan Kaštela, str. 285-298. Varaždin: Zavod za znanstveni rad Varaždin HAZU, 2009.

Krbek, Ivo. Upravno pravo: I. knjiga: Uvodna i osnovna pitanja. Zagreb: Jugoslovenska štampa, 1929.

Landikušić, Rafael. Priručnik o političkoj i sudbenoj podjeli Savske banovine. Zagreb: vlastita naklada, 1938. 
Leček, Suzana. "Izbor ili imenovanje - problem gradske (samo)uprave u Slavonskom Brodu 1918.-1941." Časopis za suvremenu povijest 45, br. 1 (2013): str. 9-33.

Pavlović, Marko. "Problem izjednačenja zakona u Kraljevini Srba, Hrvata i Slovenaca / Jugoslaviji." Zbornik Pravnog fakulteta u Zagrebu 68, br. 3-4 (2018): str. 493-523.

Pusić, Eugen. Nauka o upravi. Zagreb: Pravni fakultet, 1986.

Težak, Spomenka. "Varaždinska gradska vlast u 20. stoljeću." U 800 godina slobodnog kraljevskog grada Varaždina 1209.-2009., ur. Miroslav Šicel i Slobodan Kaštela, str. 159-168. Varaždin: Zavod za znanstveni rad Varaždin HAZU, 2009.

Vojak, Danijel. "Političko-upravne prilike na području samoborskog kotara za vrijeme šestosiječanjske diktature (1929.-1935.).” Časopis za suvremenu povijest 45, br. 1 (2013): str. 119-154.

Summary

\section{VARAŽDIN CITY GOVERNMENT IN THE INTERWAR PERIOD (1918-1941)}

The article analyzes the structure, scope and territorial jurisdiction of the Varaždin City Government, a unit of local administration that governed the Varaždin municipality in the period 1918-1941. From 1918 to 1920, the city municipality included the area of the city of Varaždin together with the villages of Varaždin Breg and Novo Selo, and from January 1, 1921 it was further expanded with the village of Šandorovec.

Two basic laws defined the structure and scope of city governments between the two world wars: the Law on the Organization of City Municipalities in the Kingdoms of Croatia and Slavonia of 1895 and the Law on City Municipalities of 1934. After the introduction of the dictatorship in 1929, two more laws were passed that had a decisive impact on the functioning of cities. One dissolved all self-governments on the territory of the state and the other annulled all existing election procedures, so that all subsequent city councils were appointed by a Ban's decision. The abolition of previous legislation, strict hierarchical supervision, the appointment of city councils and government commissioners close to the state regime and the complete denial of electoral principles led, especially in the first half of the 1930s, to the narrowing of self-governing rights of city municipalities. 
The paper presents three mutually coordinated bodies of the City Government: the council as a local representative body, committees as advisory bodies of the council and the government as an executive body.

The chapter on the city council, in addition to the structure and competencies, provides a chronological overview of the mandate of the council and a list of mayors and government commissioners who changed during the interwar years. In the 1920s, four city councils were elected and from 1929 to 1941, five were appointed. All four elected councils disbanded before the end of a six-year term due to political and party disagreements, lack of a solid coalition or personal animosities. The city council was chaired by the mayors or presidents of the city municipality. In the observed period, Varaždin had four elected and eight appointed mayors and six government commissioners. The longest-serving elected mayor was Vjenceslav Podgajski with a four-and-a-half-year term.

The council had standing committees for more efficient solution of administrative cases and faster decision making. The committees were established in accordance with the statute (Legal-Political Committee, Excise, Economic, For Paupers and Orphans, For City Enterprises, etc.) or particular legislation (School, Agricultural, Committee for Emergency Passages, Health, etc.). Their number varied over the years between twelve and eighteen.

The performance of all administrative and self-governing tasks belonged to the domain of the government, which was divided into organizational units, the so-called sections. However, little attention was paid to the organization itself. The greatest progress towards better organization was made only in 1937, when the number of departments was finally stabilized and the systematic marking of files with numerical designations of organizational units began. From then until 1941 the administrative work had been conducted in twelve and later thirteen departments (one department was established in 1938).

This article should make it easier for researchers to use the material of exceptionally valuable, frequently used and researched archival fonds of the State Archives in Varaždin, but it can also serve as a guide for understanding the administrative history of other city governments in continental Croatia, whose functioning is defined by the same legislation and the general socio-political climate of the interwar period.

Keywords: city council; city government; mayor; committees; government commissioner; city (self) government; administrative history 